\title{
Sulfur Isotope Evidence for Microbial Sulfate Reduction in Altered Oceanic Basalts at ODP Site 801
}

\author{
Olivier Rouxel $^{1, *}$, Shuhei Ono ${ }^{2, \#}$, Jeff Alt ${ }^{3}$, Douglas Rumble ${ }^{2}$ \\ and John Ludden ${ }^{4,5}$
}

${ }^{1}$ Marine Chemistry \& Geochemistry Department, Woods Hole Oceanographic Institution, MS \#25, Woods Hole MA 02543

${ }^{2}$ Geophysical Laboratory, Carnegie Institution of Washington, 5251 Broad Branch Rd. NW, Washington DC 20015

${ }^{3}$ Department of Geological Sciences, The University of Michigan, Ann Arbor, MI 48109

${ }^{4}$ Centre de Recherches Pétrographiques et Géochimiques, CNRS UPR 2300, BP 20, 54501

Vandoeuvre-les-Nancy cedex, France

${ }^{5}$ British Geological Survey, Keyworth, Nottingham, NG12 5GG, UK

* Corresponding author:

Olivier Rouxel (email: orouxel@whoi.edu; phone: 508-289-3655; fax: 508-457-2193) \# Present Address:

Department of Earth, Atmospheric, and Planetary Sciences, Massachusetts Institute of Technology, 77 Massachusetts Avenue, Cambridge, MA 02139

Keyword: sulfur isotopes, seafloor weathering, deep biosphere, oceanic crust, sulfur cycle 
The subsurface biosphere in the basaltic ocean crust is potentially of major importance in affecting chemical exchange between the ocean and lithosphere. Alteration of the oceanic crust commonly yields secondary pyrite that are depleted in ${ }^{34} \mathrm{~S}$ relative to igneous sulfides. Although these ${ }^{34} \mathrm{~S}$ depleted sulfur isotope ratios may point to signatures of biological fractionation, previous interpretations of sulfur isotope fractionation in altered volcanic rocks have relied on abiotic fractionation processes between intermediate sulfur species formed during basalt alteration. Here, we report results for multiple-S isotope $\left({ }^{32} \mathrm{~S},{ }^{33} \mathrm{~S},{ }^{34} \mathrm{~S}\right)$ compositions of altered basalts at ODP Site 801 in the western Pacific and provide evidence for microbial sulfate reduction within the volcanic oceanic crust. In-situ ion-microprobe analyses of secondary pyrite in basement rocks show a large range of $\delta^{34} \mathrm{~S}$ values, between $-45 \%$ and $1 \%$, whereas bulk rock $\delta^{34} \mathrm{~S}$ analyses yield a more restricted range of -15.8 to $0.9 \%$. These low and variable $\delta^{34} \mathrm{~S}$ values, together with bulk rock $\mathrm{S}$ concentrations ranging from $0.02 \%$ up to $1.28 \%$ are consistent with loss of magmatic primary mono-sulfide and addition of secondary sulfide via microbial sulfate reduction. High-precision multiple-sulfur isotope $\left({ }^{32} \mathrm{~S} /{ }^{33} \mathrm{~S} /{ }^{34} \mathrm{~S}\right)$ analyses suggest that secondary sulfides exhibit mass-dependent equilibrium fractionation relative to seawater sulfate in both $\delta^{33} \mathrm{~S}$ and $\delta^{34} \mathrm{~S}$ values. These relationships are explained by bacterial sulfate reduction proceeding at very low metabolic rates. The determination of the S-isotope composition of bulk altered oceanic crust demonstrates that S-based metabolic activity of subsurface life in 
22 oceanic basalt is widespread, and can affect the global $\mathrm{S}$ budget at the crust-seawater 23 interface. 


\section{Introduction}

Alteration of oceanic crust by seawater is one of the most important processes controlling the global fluxes of many elements (e.g. Staudigel and Hart, 1983) and microbes likely play a significant role in this process (Bach and Edwards, 2003). The evidence for a deep biosphere within oceanic basement includes primarily the alteration textures of volcanic glass, the potential presence of DNA or high $\mathrm{C}, \mathrm{N}$ and $\mathrm{P}$ contents in altered glass, and the light isotopic composition of $\mathrm{C}$ in some carbonate veins (e.g. Thorseth et al., 1992; Fisk et al., 1998; Furnes et al., 2001). However, the study of an active biosphere in the basaltic ocean crust is currently limited and lags behind our current understanding of subsurface life in deep-sea sediments (Parkes et al., 1994; Wortmann et al., 2001; D'Hondt et al., 2002). This is mainly due to technical difficulties involved in identifying and culturing indigenous microbes, as well as the lack of a visual record of microbial activity in crystalline rocks in contrast to volcanic glass.

Previous studies of sulfur isotope compositions of deep sea sediments have shown that sulfate-reducing communities are active in the deeply buried sediments and that their cellular metabolic activities may differ from those observed in near-surface sediments or in the water column (Wortmann et al., 2001). Sulfur isotope values of secondary pyrite precipitated in oceanic basalt fractures have been reported in numerous studies (Field et al., 1976; Krouse et al., 1977; Andrews, 1979; Puchelt et al., 1996) and $\delta^{34}$ S values generally range from basaltic values at $0 \%$ to highly negative values down to $-50 \%$. Although these negative $\delta^{34} \mathrm{~S}$ values are consistent with an origin involving microbial reduction of seawater sulfate, as commonly observed in marine sediment settings (Canfield, 2002), previous 
researchers favored an abiotic isotope fractionation process due to the lack of a wellidentified organic carbon source in the basalts (Field et al., 1976; Andrews, 1979; Puchelt et al., 1996). In a previous model, Andrews (1979) proposed that igneous sulfide minerals are partially oxidized to unstable intermediate sulfur species (e.g. sulfite, $\mathrm{SO}_{3}{ }^{2-}$, or thiosulfate, $\mathrm{S}_{2} \mathrm{O}_{3}{ }^{2-}$ ) which can inorganically disproportionate into sulfate and sulfide. Sulfate is lost from the rock, whereas sulfide, which combines with iron in the host rock, is precipitated as secondary pyrite. Recently, elevated $\delta^{34}$ S values (26.2 to $29 \%$ ) of preserved gypsum in exposed ophiolitic oceanic crust have been interpreted as the result of in-situ microbial sulfate reduction (Alt et al., 2003) but questions remain concerning the origin (i.e. abiotic or biotic), mechanisms (i.e. sulfate reduction or disproportionation), and global significance of the low $\delta^{34} \mathrm{~S}$ values in secondary sulfides in altered basalts.

Drilling at Ocean Drilling Program (ODP) Site 801 penetrated more than $400 \mathrm{~m}$ into Jurassic oceanic basement in the western Pacific (Larson et al., 1992; Plank et al., 2000). This section represents the oldest in-situ oceanic basement ever drilled and presents an excellent opportunity to explore potential S-isotope biosignatures of the deep biosphere. In this paper, we use three $\mathrm{S}$ isotope approaches to unravel the mechanisms of S-isotope fractionation associated with the alteration of the oceanic crust at ODP Site 801. First, insitu ion microprobe $\delta^{34} \mathrm{~S}$ analyses were undertaken to document isotopic heterogeneity and textural relationship for secondary sulfides in altered rocks and veins. Second, analyses of multiple S-isotopes $\left({ }^{32} \mathrm{~S}{ }^{\beta 3} \mathrm{~S}{ }^{\beta 4} \mathrm{~S}\right)$ for selected secondary sulfides in the altered basalts were used to constrain multiple-sulfur isotope relationships between primordial sulfur and seawater sulfate. Analysis of $\delta^{33} \mathrm{~S}$ combined with standard $\delta^{34} \mathrm{~S}$ analysis provides a new 
dimension in documenting reactions involving sulfur, such as reaction pathways during microbial sulfate reduction and S-disproportionation (Farquhar et al., 2003; Johnston et al., 2005; Ono et al., 2006). Finally, bulk rock S-isotope analyses are used to assess the largescale budget of sulfur isotopes in altered oceanic basement at ODP Site 801 .

\section{Geological setting and alteration history}

ODP Site 801 is located in the Pacific plate several hundred kilometers east of the Marianas trench (Fig.1). ODP Site 801 was drilled into Jurassic basement characterized by a lack of magnetic anomalies and a half-spreading rate of about $8 \mathrm{~cm} / \mathrm{yr}$ (Larson et al., 1992; Plank et al., 2000). On the basis of flow morphology, geochemistry, and mineralogy, the basement section at Hole $801 \mathrm{C}$, which was intersected at 461.6 meters below seafloor (mbsf), has been divided into four major sequences which include rocks drilled on both Leg 129 and Leg 185 (Larson et al., 1992; Plank et al., 2000; Kelley et al., 2003) (Fig. 2).

The uppermost basement (Unit ALK) is composed of alkaline basaltic to dolerite sills overlying a $\mathrm{Si}$ and $\mathrm{Fe}$ oxyhdroxide-rich hydrothermal horizon (H.D. in Fig.2). The alkali basalt section is younger (157 Ma; Pringle, 1992; Koppers et al., 2003) than the underlying tholeiitic mid-ocean ridge basalt (MORB) section ( 170 Ma). Below the hydrothermal deposit, the volcanic rocks (Unit MORB 0-110) comprise thin flows and pillows, lying above a series of thick lava flows. The upper $110 \mathrm{~m}$ of MORB (MORB 0-110 of Fig.1) are thought to have erupted slightly off-axis (Pockalny and Larson, 2003). The on-axis MORB is divided into a middle (MORB 110-220) and a lower (MORB 220-420) unit, distinguished on the basis of a change in eruptive styles, with more massive flows in the lower unit. Between 600 and 720 mbsf the section is characterised by a pillow- 
91 dominated zone with a well-developed interpillow horizon (Unit MORB 110-220). A second Si-Fe-rich hydrothermal unit similar to the larger one uphole is present within Unit MORB 110-220 pillows (Fig. 2). From 720 mbsf to the bottom at $936 \mathrm{mbsf}$, the Unit MORB 220-420 comprises a tectonic breccia which separates a massive flow unit (720-890 mbsf) and a series of thin, generally $<1$-m-thick, sheet flows and pillows (890-934 mbsf).

Three general types of low temperature alteration can be observed (Alt and Burdett, 1992; Plank et al., 2000; Talbi and Honnorez, 2003): (1) replacement of igneous material in alteration halos and groundmass; (2) filling of void space by secondary phases; (3) development of breccia cements and cross-cutting veins. The latter are often filled with calcite, and can reopen and refill for millions of years, providing an important sink for carbon in the altered crust (Alt and Teagle, 1999). The most common secondary phases are saponite (Mg-smectite), calcite, celadonite, Fe-oxyhydroxide and pyrite (Alt and Teagle, 2003; Talbi and Honnorez, 2003). Most of the basalts are dark gray in color and have experienced 10 to $20 \%$ alteration (Alt and Teagle, 2003). In addition, both dark celadoniterich, and brown Fe-oxyhydroxide alteration halos around fractures are observed. Secondary pyrite generally occurs within saponite-rich and carbonate veins but is also found at the boundary between the alteration halos and the host rock. Alteration of basalts at Site 801 took place at low temperatures $\left(<100^{\circ} \mathrm{C}\right)$, mainly off-axis, during aging of the oceanic crust (Plank et al., 2000; Alt and Teagle, 2003; Talbi and Honnorez, 2003). Fresh basaltic glass is locally preserved at Site $801 \mathrm{C}$, demonstrating the heterogeneous distribution of low temperature alteration. Volcanic glass recovered throughout the section is altered by invasive channels and tubes which are similar to other examples in basaltic glass in the deep ocean crust that have been attributed to microbial alteration (Plank et al., 2000). 
115 3. Methodology

116

$117 \quad 3.1$ Sampling strategy

118 A comprehensive set of samples, covering the major Units at Site 801, were selected

119 for this study (Table 1). All of the selected rocks have been affected by low temperature

120 alteration $\left(<100^{\circ} \mathrm{C}\right)$ resulting in various combinations of secondary minerals saponite $(\mathrm{Mg}-$

121 smectite), calcite, celadonite, Fe-oxyhydroxide and pyrite as replacements of igneous

122 phases and as fillings of vesicles and cracks. A subset of samples was also selected for in-

123 situ S-isotope analysis based on the occurrence of macroscopic pyrite along veins and

124 disseminated in the groundmass (Table 2).

125 We analyzed one composite sample (referred as SUPER) which represents a

126 physical mixture of a subset of individual samples covering all basement lithologies

127 identified at site 801C (Plank et al., 2000; Revillon et al., 2002; Kelley et al., 2003). This

128 SUPER composite was prepared by making a proportionate mixture of sub-composites

129 (volcanic flows and volcanoclastites) from each of the three MORB intervals. These sub-

130 composites were themselves prepared from 117 representative samples from each core

131 segments from the basement section of Hole 801C (Kelley et al., 2003). Though detailed

132 information about fine-scale variations can be obtained only from the analysis of individual

133 samples, the use of composites allows to estimate the average composition with very few

134 analyses. Hence, we used S concentration and S-isotope composition of the SUPER

135 composite to approximate the large-scale composition of the entire MORB section at Site 136801. 


\subsection{S-isotope definitions and notations}

$140 \quad \delta^{\mathrm{x}} \mathrm{S}=\left(\frac{{ }^{\mathrm{x}} R_{\text {sample }}}{{ }^{\mathrm{x}} R_{\text {reference }}}-1\right) \times 1,000 \quad(\% \mathrm{o})$

141 where ${ }^{\mathrm{x}} R$ is the isotope ratio, ${ }^{\mathrm{x}} \mathrm{S} /{ }^{32} \mathrm{~S}(\mathrm{x}=33$ or 34$)$, of the sample compared to reference

142 material. S-isotope data are reported on the Vienna-CDT scale (VCDT) by defining $\delta^{33} \mathrm{~S}$

143 and $\delta^{34} \mathrm{~S}$ of IAEA S-1 (artificial $\mathrm{Ag}_{2} \mathrm{~S}$ ) to be -0.055 and $-0.300 \%$, respectively (Coplen 144 and Krouse, 1998; Ono et al., 2007).

145 We define traditional capital delta notation $(\Delta)$ as deviations of $\delta^{33} \mathrm{~S}$ from a reference 146 line :

$$
\Delta^{33} \mathrm{~S}=\delta^{33} \mathrm{~S}-0.515 \times \delta^{34} \mathrm{~S}
$$

151 where

$152 \quad \delta^{x} \mathrm{~S}^{*}=\ln \left(\frac{{ }^{x} R_{\text {sample }}}{{ }^{x} R_{\text {ref }}}\right) \times 1,000=\ln \left(\frac{\delta^{x} \mathrm{~S}}{1,000}+1\right) \times 1,000$ Both definitions ( $\Delta$ and $\Delta^{*}$ ) are used in Table 3 for comparison. Note that the 154 modified delta notations $\left(\delta^{34} \mathrm{~S}^{*}\right.$ and $\left.\Delta^{33} \mathrm{~S}^{*}\right)$ are fractionation-oriented (i.e. linear 155 relationships during mass-dependent isotope fractionation) whereas traditional delta 
156 coordinates $\left(\delta^{34} \mathrm{~S}\right.$ and $\left.\Delta^{33} \mathrm{~S}\right)$ are mass-balance oriented (i.e. linear relationships during 157 mixing) (Ono et al., 2007).

158 Mass-dependent sulfur isotope fractionation factors are described by the following 159 power law (Hulston and Thode, 1965; Farquhar et al., 2003; Ono et al., 2007) :

160 ${ }^{33} \alpha={ }^{34} \alpha{ }^{33} \theta$

161 where fractionation factors $\left({ }^{\mathrm{x}} \alpha\right)$ are defined as the ratio of ${ }^{\mathrm{x}} \mathrm{S} /{ }^{32} \mathrm{~S}$ between two pools of 162 sulfur (e.g., A and B). That is,

$163{ }^{\mathrm{x}} \alpha=\left({ }^{\mathrm{x}} \mathrm{S} /{ }^{32} \mathrm{~S}\right)_{\mathrm{A}} /\left({ }^{\mathrm{x}} \mathrm{S} /{ }^{\beta 2} \mathrm{~S}\right)_{\mathrm{B}}$

164 The ${ }^{33} \theta$ value for equilibrium isotope fractionation factors between $\mathrm{SO}_{4}{ }^{2-}$ and $\mathrm{H}_{2} \mathrm{~S}$

165 may also vary as a function of temperature, from 0.5145 at $0^{\circ} \mathrm{C}$ to 0.5154 at $500^{\circ} \mathrm{C}$ (Ono et 166 al., 2007) while microbial sulfate reduction follows different ${ }^{33} \theta$ value of $\sim 0.512$ (Farquhar 167 et al., 2003; Ono et al., 2007).

168

169 3.3. Bulk rock analysis:

170 Solid sample surfaces were cleaned with a sand-blaster and washed with distilled

171 water. Sample powders for bulk rock analysis were prepared using agate grinding vessels.

172 Major element chemistry was determined by ICP-AES at CRPG-CNRS (France) following

173 the procedure described in Govindaraju and Mevelle (1987) and results are presented in

174 Table 1. S concentrations were analyzed in $250 \mathrm{mg}$ bulk rock samples using a

175 LECO144DR carbon-sulfur analyzer. The precision is estimated at 5\% for S content $176>0.05 \%$ and the limit of detection is $0.005 \%$. 
178 of Rice et al. (1993) and Canfield et al. (1986) and data are reported in Table 1. Acid-

179 volatile sulfides (AVS) were first extracted in $\mathrm{HCl}$ with $\mathrm{SnCl}_{2}$ added to prevent oxidation.

180 Chromium-reducible sulfides (Cr-S) were subsequently extracted using the Cr-reduction

181 method (Table 1). Evolved $\mathrm{H}_{2} \mathrm{~S}$ for AVS and $\mathrm{Cr}-\mathrm{S}$ were precipitated as $\mathrm{Ag}_{2} \mathrm{~S}$, and acid

182 soluble sulfate was reduced to $\mathrm{H}_{2} \mathrm{~S}$ with Thode's solution and precipitated as $\mathrm{Ag}_{2} \mathrm{~S}$. Sulfur

183 isotope analyses of $\mathrm{Ag}_{2} \mathrm{~S}$ were performed at Queen's University (Canada). Yields from the

184 sulfur extractions average $90 \%$ of the bulk S concentrations from LECO C-S analyzer, but

185 only the latter are reported. Total $\delta^{34} \mathrm{~S}$ composition is obtained by mass balance calculation

186 between AVS and Cr-S.

187

188

189

190

191

192

193

194

195

196

197

198

\subsection{Micro-drilled sulfide analysis:}

The ${ }^{34} \mathrm{~S} /{ }^{32} \mathrm{~S}$ analyses of micro-drilled sulfides (Table 2) were performed on a VG602D double-collector mass spectrometer at CRPG and are given in conventional $\delta^{34} \mathrm{~S}$ notation relative to V-CDT (Coplen and Krouse, 1998). We used the NIST sulfide standard NZ-1 defined at $-0.3 \%$ and we obtained NZ-2 $=21.6 \%$ $\pm 0.1 \%$, NZ-3 $=-31.6 \%$ $\pm 0.1 \%$, NBS-123 $=17.4 \%$ $\pm 0.1 \%$, NBS-127= $20.4 \%$ $\pm 0.2 \%$ based on replicate measurements. The precision for sulfide data is typically $\pm 0.2 \%$ ( 2 sigma level $)$ and is often better than $0.1 \%$.

The ${ }^{34} \mathrm{~S} /{ }^{32} \mathrm{~S}$ and ${ }^{33} \mathrm{~S} /{ }^{32} \mathrm{~S}$ analyses were performed at the Carnegie Institution of Washington (USA). The fluorination manifold is coupled on-line with a two-stage gas chromatography purification system, which is critical for ultra-high precision isotope ratios 
measurements. Multiple sulfur isotope ratios are analyzed by a gas-source massspectrometer (Finnigan MAT 253) with $\mathrm{SF}_{6}$ as analyte. Details of the analytical technique

201 can be found in $\mathrm{Hu}$ et al. (2003) and Ono et al. (2006). For isotope analysis, $\operatorname{Ag}_{2} \mathrm{~S}(\sim 1.5$ mg) were prepared by conventional distillation (Cr-reduction) after precise micro-drilling

203 of rock matrix containing large sulfide grains in polished section (Supplementary 204 Materials). Precision and accuracy are 0.2 and $0.004 \%$ for $\delta^{34} \mathrm{~S}$ and $\Delta^{33} \mathrm{~S}$, respectively

205 (Ono et al., 2006). Isotope results are reported in Table 3.

\subsection{Ion-microprobe analysis:}

$\mathrm{S}$ isotope compositions of pyrite and marcasite, ranging in size from $100 \mu \mathrm{m}$ up to 2

$209 \mathrm{~mm}$ in diameter, hosted in the basalt groundmass or occurring within vein fractures (Table

2102 and Fig. 2) were determined using a modified CAMECA IMS 3F ion microprobe at the

211 CRPG (Chaussidon and Demange, 1988). Rock chips were mounted in epoxy together with

212 an internal pyrite S-isotope standard (GAV18), polished, and coated with gold. Sulfides

213 were sputtered with a $10-15 \mathrm{nA} \mathrm{O}^{-}$primary beam of $50 \mu \mathrm{m}$ in diameter. Secondary ${ }^{32} \mathrm{~S}^{+}$and

$214{ }^{34} \mathrm{~S}^{+}$ions were analyzed in mono-collector mode without energy filtering at a mass

215 resolution of 3000 as no sulfur hydrides were observed. The instrumental mass

216 fractionation (the difference between $\delta^{34} \mathrm{~S}$ obtained with the ion probe and the true value)

217 was determined at $-47 \%$ using the internal standard GAV18 defined at $10.5 \%$ relative to

218 V-CDT. Under normal conditions, the internal precision of S-isotope analysis is about

219 1.0\%o. However, during the analytical period of this study, reproducibility of the standard

220 measured between each sample data point in the same polished section was somewhat 
221 poorer $(2.0 \%$ at $95 \%$ confidence level for 40 analyses). This is mainly due to instability of 222 the primary gun and/or change of instrumental bias during repositioning of the sample.

\section{Results and Discussion}

\section{1. ${ }^{34} S-{ }^{32} S$ isotope profile through basaltic oceanic crust section}

S-isotope analyses of bulk basalt and individual Fe-sulfide grains (pyrite and

228

229 marcasite) display a large spread of $\delta^{34} \mathrm{~S}$ values from $1.3 \%$ down to $-45 \%$ (Fig.2). In situ ion-microprobe analyses reveal that $\delta^{34} \mathrm{~S}$ values lower than $-20 \%$ o (e.g. sample $801 \mathrm{~B}-$ $43 \mathrm{R} 1,29 ; 801 \mathrm{C}-39 \mathrm{R} 2,28)$ are commonly found in pyrite and marcasite precipitated in open space of altered basalts, such as within mm-thick carbonate veins, thin fractures lined with saponite or in vesicles (Fig.3). In contrast, $\delta^{34} \mathrm{~S}$ values higher than $-10 \%$ (e.g. sample 801C-24R2,36; 801C-37R1,83) are preferentially found for secondary sulfides disseminated within the basalt matrix. Although significant isotopic variations of up to $10 \%$ occur at sub-mm scales, showing the existence of several generations of sulfide minerals having distinct S-isotope compositions (Fig.3), no systematic $\delta^{34} \mathrm{~S}$ zonation within sulfide grains could be identified. As evident from Figure 2, no clear trend can be drawn along the depth profile and highly negative $\delta^{34} \mathrm{~S}$ values analyzed by ion microprobe are found at the greatest depth $(840 \mathrm{mbsf})$. As expected, $\mathrm{S}$ isotope compositions of bulk rocks do not display the same degree of variability as for in situ analysis and $\delta^{34} \mathrm{~S}$ values for both AVS and Cr-S vary between 0.9 and $-15.8 \%$. In general, AVS yields higher $\delta^{34} \mathrm{~S}$ values than $\mathrm{Cr}-\mathrm{S}$ by up to $5 \%$, although some samples (e.g. $801 \mathrm{C}-37 \mathrm{R} 1,83$ ) display inverse 
243 relationships. Less negative $\delta^{34} \mathrm{~S}$ values for AVS are explained by considering that AVS

244 fraction preferentially sampled primary pyrrhotite having primordial isotope compositions $245\left(\delta^{34} \mathrm{~S} \approx 0 \%\right.$. The SUPER composite yields negative $\delta^{34} \mathrm{~S}$ values of $-2.7 \%$ for AVS and 246 8.4\% for $\mathrm{Cr}-\mathrm{S}$, with the bulk sulfide-S (i.e., AVS $+\mathrm{Cr}-\mathrm{S}$ ) of the uppermost $440 \mathrm{~m}$ of 247 volcanic basement at Site 801 having $\delta^{34} \mathrm{~S}=-6.8 \%$. concentrations (Table 1) ranging from values lower than $0.02 \%$ to values up to $1.28 \%$.

250 Based on electron microprobe analyses of fresh volcanic glass recovered through the 801C 251 tholeiitic section, primary magmatic $\mathrm{S}$ contents are estimated, on average, to be $0.21 \pm 0.06$ $252 \mathrm{wt} \%$ (Fisk and Kelley, 2002). Since magma degassing at the seafloor leads to loss of, on 253 average, one third of the sulfur in the melt (Moore and Fabbi, 1971), S concentration of the 254 fresh crystalline $801 \mathrm{C}$ basalt section is estimated between 0.17 and $0.12 \mathrm{wt} \%$. Bulk rock 255 analysis of altered basalts at ODP Site 801 (Table 1) reveal that some intervals may display 256 S-enrichment relative to fresh basalts (S up to 1.30\%, sample 801C-37R5,30) and negative $257 \delta^{34} \mathrm{~S}$ values (-12.9\%o). These discrete intervals are best explained by a net addition of 258 secondary sulfide having negative $\delta^{34}$ S. It should be also noted that S-depleted altered 259 basalt, such as sample $(801 \mathrm{C}-15 \mathrm{R} 4,69)$ may also display minimal S-isotope fractionation, 260 suggesting that sulfide oxidation may proceed without significant S-isotope fractionation. An important question to address is whether these low and highly variable $\delta^{34} \mathrm{~S}$ 262 values and S-enrichment through the basaltic oceanic crust section at ODP Site 801 result 263 from the downward diffusion (or advection) of $\mathrm{H}_{2} \mathrm{~S}$ from overlying sediment section or 264 result from in-situ S-isotope fractionation. Sediments at Site 801 are mostly oxidized 
265 pelagic sediments, composed of chert, porcellanite and volcaniclastic turbidites with very 266 little organic carbon (Alt and Burdett, 1992). As a consequence, sulfate reduction is limited 267 throughout the overlying sediment section at ODP Site 801, as demonstrated by porewater 268 sulfate concentrations above $16 \mathrm{mM}$ and the lack of detectable level of dissolved sulfide in 269 porewaters (Alt and Burdett, 1992). In addition, the thick chert and porcellanite Units at 270801 provide a low-permeability barrier to vertical diffusion between upper sediments and 271 deeper volcaniclastic turbidites. These layers would have prevented diffusion of $\mathrm{H}_{2} \mathrm{~S}$ and 272 nutrients into the basement from any organic rich sediments deposited in the high273 productivity equatorial upwelling zone at about 90-80 Ma (Alt and Burdett, 1992). (between -14 to $-21 \%$, Alt and Burdett, 1992) than for secondary pyrite in the underlying 276 altered basement, together with the lack of a systematic downhole trend in $\delta^{34} \mathrm{~S}$ values 277 along the volcanic section (Fig. 2) suggest an in-situ sulfate reduction origin for secondary 278 sulfide in the volcanic basement at Site 801. In fact, the large heterogeneity of $\delta^{34} \mathrm{~S}$ values 279 for secondary pyrite within individual samples (e.g. sample 801C-17R1,100; Table 2) is 280 better explained by in-situ S-isotope fractionation within basement rather than sedimentary 281 origin. Low $\delta^{34} \mathrm{~S}$ values of pyrite and marcasite in open space (veins) between -35 to -45 $282 \%$ are thus consistent with open-system bacterial sulfate reduction under unlimited sulfate 283 supply. In contrast, higher $\delta^{34} \mathrm{~S}$ values up to $0 \%$ could reflect either closed-system bacterial 284 sulfate reduction or mixing between biogenic and igneous (i.e. unfractionated) sulfides.

285 It remains unclear, however, whether these highly negative $\delta^{34} \mathrm{~S}$ values down to -45 $286 \%$ are generated by (1) abiotic fractionation during sulfide partial oxidation and 
reprecipitation, as suggested previously by Andrews (1979); (2) single-step bacterial sulfate reduction, as suggested from deep marine sediments porewater studies (Wortmann et al., 2001); (3) bacterial disproportionation of intermediate S-species, as commonly proposed for sedimentary sulfides (Canfield and Thamdrup, 1994). Comparisons between $\delta^{34} \mathrm{~S}$ values and $\mathrm{S}$ concentrations of altered basalts as well as multiple S-isotope systematics may help in solving these issues as described below.

\subsection{Mechanisms of S loss and uptake during seafloor weathering}

Andrews (1979) proposed that the partial oxidation of magmatic sulfides at low temperature could account for depletions in $\mathrm{S}$ as well as for the observed negative $\mathrm{S}$ isotopic compositions. Because the partial oxidation of sulfide under conditions of limited oxygen supply could lead to the formation of unstable $\mathrm{S}$ species of intermediate oxidation state, i.e. sulphite $\mathrm{SO}_{3}{ }^{2-}$, thiosulfate $\mathrm{S}_{2} \mathrm{O}_{3}{ }^{2-}$ and elemental $\mathrm{S}^{\circ}$ (Zhang and Millero, 1993), the following disproportionation reactions may occur:

$$
\begin{aligned}
& \mathrm{S}_{2} \mathrm{O}_{3}{ }^{2-}+\mathrm{H}_{2} \mathrm{O}=\mathrm{H}_{2} \mathrm{~S}+\mathrm{SO}_{4}{ }^{2-} \\
& 4 \mathrm{SO}_{3}{ }^{2-}+2 \mathrm{H}^{+}=\mathrm{H}_{2} \mathrm{~S}+3 \mathrm{SO}_{4}{ }^{2-} \\
& 4 \mathrm{~S}^{\circ}+4 \mathrm{H}_{2} \mathrm{O}=3 \mathrm{H}_{2} \mathrm{~S}+\mathrm{SO}_{4}{ }^{2-}+2 \mathrm{H}^{+}
\end{aligned}
$$

In principle, equilibrium fractionation of S-isotopes between the oxidized and reduced species in reactions (7), (8) and (9) could lead to enrichment of ${ }^{34} \mathrm{~S}$ in sulfate and a corresponding depletion of ${ }^{34} \mathrm{~S}$ in sulfide (Ohmoto and Lasaga, 1982). However, the major drawback of this hypothesis is that it requires isotopic exchange between sulfate and sulfonate-sulfur of thiosulfate or sulfide-sulfur before pyrite precipitation. This is highly 
309 unlikely, considering the very slow rate, on the order of $10^{6} \mathrm{yr}$, of equilibrium isotopic 310 exchange between sulfide and sulfate at temperature $<100^{\circ} \mathrm{C}$ (Sakai and Dickson, 1978;

311 Ohmoto and Lasaga, 1982). It has been also shown that the intramolecular isotope 312 exchange of thiosulfate is sufficiently fast to produce isotopically light pyrite even at low 313 temperature, mostly because the sulfonate $\mathrm{S}$ of thiosulfate is strongly enriched in ${ }^{34} \mathrm{~S}$ 314 relative to the sulfane $\mathrm{S}$ (Uyama et al., 1985; Chu et al., 2004). However, the 315 disproportionation of thiosulfate (reaction 7) has been shown to proceed at very slow rates 316 for temperatures below $120^{\circ} \mathrm{C}$ (Uyama et al., 1985). In addition, recent studies (Bak and 317 Cypionka, 1987; Jorgensen, 1990; Canfield and Thamdrup, 1994; Cypionka et al., 1998; 318 Habicht et al., 1998) have demonstrated that the disproportionation reactions of thiosulfate, 319 sulfite and elemental $\mathrm{S}$ in nature are more likely biologically catalyzed processes rather 320 than inorganic reactions at low temperatures $\left(\right.$ i.e. $\left.<100^{\circ} \mathrm{C}\right)$. relative importance of the formation of $\mathrm{SO}_{4}{ }^{2-}$ through complete oxidation (i.e., without isotope fractionation) and, potentially through partial oxidation (i.e., disproportionation) of

325 intermediate S-species, it is possible to predict theoretically the relationship between $\delta^{34} \mathrm{~S}$ 326 values and S concentrations of altered basalts .

327 The distillation equation linking the fraction $F$ of $S$ loss during partial sulfide 328 oxidation and the $\mathrm{S}$ isotope ratios of the residual $\mathrm{S}$ pool $\left(\delta^{34} \mathrm{~S}_{\beta}\right)$ is:

$$
\delta^{34} \mathrm{~S}_{\beta}=\left(1000+\delta^{34} \mathrm{~S}_{\mathrm{o}}\right) * \mathrm{~F}^{(\alpha-1)}-1000
$$


330 where $\delta^{34} \mathrm{~S}_{\mathrm{o}}$ is the initial $\mathrm{S}$ isotopic composition of basalt, $\alpha$ the fractionation factor 331 between intermediate $\mathrm{S}$-species and sulfate generated by the reactions of $\mathrm{S}$ 332 disproportionation (7), (8) or (9). Examples of relationships between S-isotope 333 composition and S concentration are presented in Figure 4 for the case of complete S 334 oxidation (i.e. no S-isotope fractionation) and partial oxidation reactions (curves (d) and 335 (c) of Fig. 4, respectively).

336 We are not aware of experimental investigation of S-isotope fractionation during 337 chemical (i.e. abiotic) disproportionation of intermediate $\mathrm{S}$ species which are relevant to 338 low temperature (i.e. $<100^{\circ} \mathrm{C}$ ) conditions. Hence, partial S oxidation pathways are 339 calculated using equation (10) in the case of microbial disproportionation reactions where $340 \quad{ }^{34} \mathrm{~S}$ enrichment in sulfate is $13 \%$. Smaller fractionation factors $\alpha$ near 1.004 can result from 341 microbial disproportionation of thiosulfates $(\alpha=1.001)$ and sulfite $(\alpha=1.009)$ (Habicht et al., 342 1998) whereas the disproportionation of elemental $\mathrm{S}$ will result in larger fractionation 343 factors $(\alpha=1.013)$ (Canfield and Thamdrup, 1994). Smaller fractionation factors or a 344 combination of complete $\mathrm{S}$ oxidation and disproportionation will produce $\mathrm{S}$ vs. $\delta^{34} \mathrm{~S}$ 345 relationships lying between model curves (c) and (d) in Figure 4. Hence, altered basalts 346 with low $\mathrm{S}$ concentrations and $\delta^{34} \mathrm{~S}$ values are consistent with - but do not necessarily 347 prove - S-isotope fractionation during partial S oxidation reactions. In contrast, altered 348 basalts with negative $\delta^{34} \mathrm{~S}$ values but higher $\mathrm{S}$ concentrations (i.e. lying on the right side of 349 model curve (c) in Fig. 4) require a net addition of sulfides with low $\delta^{34} \mathrm{~S}$ values, which 350 likely derived from the bacterial reduction of seawater sulfate. 

reduction of seawater sulfate with low $\delta^{34} \mathrm{~S}$ values, we calculated the theoretical mixing

353 (mix) between basaltic S (bas) and biogenic S (bio) using the relation :

$$
\delta^{34} \mathrm{~S}_{\mathrm{mix}}=\left(\mathrm{S}_{\mathrm{bio}} \delta^{34} \mathrm{~S}_{\mathrm{bio}}+\mathrm{S}_{\mathrm{bas}} \delta^{34} \mathrm{~S}_{\mathrm{bas}}\right) / \mathrm{S}_{\mathrm{mix}}
$$

355 where $\delta^{34} \mathrm{~S}_{\text {bio }}$ is calculated using the difference between $\delta^{34} \mathrm{~S}$ of Jurassic seawater $\left(\delta^{34} \mathrm{~S}\right.$ $356 \sim 15 \%$, Claypool et al., 1980) and the fractionation factor during bacterial sulfate reduction. 357 As presented in Figure 4, all basalt samples (except one sample at $871 \mathrm{~m}$ depth) require a 358 fractionation factor $\alpha_{\mathrm{SO} 4-\mathrm{H} 2 \mathrm{~S}}$ larger than $\sim 1.025$ (curve (a), Fig. 4) in order to produce the observed $\delta^{34} \mathrm{~S}$ vs. S concentration relationships. The addition of S with highly negative $\delta^{34} \mathrm{~S}$ values are further confirmed by ion-microprobe analysis of individual pyrite showing the 361 occurrence of $\delta^{34} \mathrm{~S}$ values down to $-45 \%$.

362

\subsection{Timing of S loss and uptake during low-temperature alteration}

Based on the scattered relationship between $\mathrm{S}$ concentration and $\delta^{34} \mathrm{~S}$ values seen in 365 bulk rock (Fig.4), it is evident that altered basalts at ODP 801 are affected by a combination 366 of S-depletion during sulfide oxidation and secondary S-enrichment due to bacterial sulfate 367 reduction. In most cases, basalt groundmass is affected by S-loss due to oxidative seafloor 368 weathering whereas saponite or calcite-rich veins may have secondary pyrite enrichment reflecting more reducing conditions. The timing of such S-loss and enrichment is presently 370 unclear but may represent various stages of alteration processes. Alt and Teagle (2003) 371 defined the following multi-stage alteration sequence, which is similar to that described by 372 Talbi and Honnorez (2003). Alteration started in places of high fluid/rock ratio, forming 
373 celadonite-rich and Fe-oxyhydroxide alteration halos along fractures. Alteration proceeded 374 away from fractures and into the host rock where lower fluid/rock ratios and more reducing 375 conditions favored the production of smectite and secondary pyrite. As redox conditions 376 changed with time, the formation of phases characteristic of reducing conditions can be 377 observed in previously oxidized rocks. Eventually the entire system became reducing, as 378 demonstrated by the presence of late-stage veins of smectite, calcite, and pyrite. Calcite 379 typically forms the latest minerals that cross-cut all others (Alt and Teagle, 1999) which is 380 consistent with a long duration of alteration ( $>50 \mathrm{Ma})$ as suggested by heat flow data and 381 isotopic ages of secondary phases from the oceanic crust (Staudigel, 2003). Hence, 382 precipitation of secondary pyrite in veins at Site 801 may continue for protracted periods, 383 possibly up to $50 \mathrm{Ma}$ after crust formation of ridge axis. This hypothesis is also consistent 384 with a recent study of Re and Os concentrations and Os isotopic ratios in altered basalt at 385 ODP Site 801 (Reisberg et al., 2007) which suggest significant Re uptake during low386 temperature alteration. Model ages of Re addition for altered basalts range from 78 to 160 387 Ma, which likely represent the average ages of long-lived processes rather than specific 388 events. Since secondary pyrite may have accommodated an important part of the input Re 389 (Reisberg et al., 2007), these relatively young model ages suggest that secondary pyrite 390 precipitation may continue for tens of millions of years after crust formation.

391 Microbial communities that colonise the basaltic surface layer at mid-oceanic ridges 392 may become buried below several hundred meters during seafloor spreading and ageing of 393 the oceanic crust. The microbial community may either die during burial or persist to 394 generate deep biosphere in the ocean crust. The highly negative and heterogeneous $\delta^{34} \mathrm{~S}$ 
395 values of late-stage pyrite found at a depth of up to $834 \mathrm{mbsf}$ (i.e. $340 \mathrm{~m}$ into the basement)

396 demonstrate there is active S-based metabolism during aging of the altered ocean crust at 397 ODP Site 801.

398

\section{4. ${ }^{34} S-{ }^{33} S-{ }^{32} S$ isotope biosignatures in secondary sulfides in oceanic basement} conventional $\delta^{34} \mathrm{~S}$ analyses alone (Farquhar et al., 2003; Johnston et al., 2005; Ono et al., 402 2006). The isotope composition of primordial sulfur (e.g. primary sulfide in basalt) is 403 defined at $\Delta^{33} \mathrm{~S}=0 \%$ (Fig. 5). Analyses of modern seafloor hydrothermal sulfide minerals 404 and vent fluid $\mathrm{H}_{2} \mathrm{~S}$ show a slight enrichment of ${ }^{33} \mathrm{~S}(<0.03 \%$ ) which is interpreted to reflect 405 local isotope exchange between seawater sulfate and vent sulfide at temperatures $>300^{\circ} \mathrm{C}$ 406 occurring near or at the seafloor (Ono et al., 2007). In contrast, biogenic sulfide data (Ono 407 et al., 2007) plot above the equilibrium mass-dependent fractionation line between $\mathrm{SO}_{4}{ }^{2-}$ 408 and $\mathrm{H}_{2} \mathrm{~S}\left({ }^{33} \alpha \approx^{34} \alpha^{0.515}\right.$, Fig. 5), consistent with experimental studies showing that microbial 409 sulfate reduction follows a slightly different mass-dependent law $\left({ }^{33} \alpha \approx^{34} \alpha^{0.512}\right.$, (Farquhar et 410 al., 2003; Johnston et al., 2005).

411 Results of multiple-sulfur isotope analyses at ODP Site 801 are presented in Figure 4125 and define a unique domain in $\delta^{34} \mathrm{~S}$ vs. $\Delta^{33} \mathrm{~S}$ relationships which is strikingly different 413 from natural hydrothermal and sedimentary biogenic pyrite measured in previous studies 414 (Ono et al., 2006; Ono et al., 2007). These data show at least two generations of secondary 415 pyrite in altered basalt. One is depleted in ${ }^{34} \mathrm{~S}$ with $\delta^{34} \mathrm{~S}$ ranging from -34.5 to $-41.5 \%$, and 416 plots on the equilibrium mass-fractionation line with respect to seawater sulfate, suggesting 
417 that these sulfides are derived from reduction of seawater sulfate through near equilibrium 418 processes. The apparent equilibrium isotope fractionation factor $\alpha$ between sulfate and 419 sulfide ranges from 1.056 to 1.062 which corresponds to an equilibration temperature of $420 \sim 60^{\circ} \mathrm{C}$, consistent with the estimated temperature of basalt alteration (Alt and Teagle, 421 2003). In Figure 5, the equilibrium fractionation line is calculated based on equilibrium S422 isotope fractionation between $\mathrm{H}_{2} \mathrm{~S}$ and present day seawater sulfate (Ono et al., 2007). 423 Since the $\delta^{34} \mathrm{~S}$ of seawater sulfate has varied in the past, increasing from the present day 424 value of $21 \%$ to about $23 \%$ in the Miocene, then decreasing to about $15 \%$ in the lower 425 Cretaceous (Claypool et al., 1980), $\Delta^{33} \mathrm{~S}$ values of seawater sulfate would have been also 426 different for the past. Multiple S-isotope analysis of carbonate-associated sulfate of Jurrasic 427 age (184-176 Ma) (Ono and Lyons, unpub results), however, yield $\Delta^{33} \mathrm{~S}$ values between 4280.001 to $0.02 \%$, which are not significantly different from that of modern seawater (Fig. 5). Another set of sulfides are characterized by intermediate $\delta^{34} \mathrm{~S}$ values ranging from $430 \quad 21.4$ to $-25.8 \%$ and plot below the equilibrium mass-fractionation line. In order to evaluate 431 the relationships between these two groups of data, we calculated various mixing lines in $432 \quad \delta^{34} \mathrm{~S}$ vs. $\Delta^{33} \mathrm{~S}$ coordinates (Figure 5) between secondary pyrite and magmatic sulfides. The 433 results suggest that pyrite with $\delta^{34} \mathrm{~S}$ values ranging from -21.4 to $-25.8 \%$ are best 434 explained by mixing of primary basaltic sulfide with sulfides that are isotopically 435 equilibrated with seawater sulfate and having $\delta^{34} \mathrm{~S}$ values $<-34.5 \%$. In one case, it appears 436 that the addition of secondary pyrite with $\delta^{34} \mathrm{~S}$ as low as $-50 \%$ is required for sample 437 801C-9R1 but such extremely depleted $\delta^{34} \mathrm{~S}$ values have not been found using in-situ 438 techniques. 
The most striking feature of the multiple-sulfur isotope systematics at ODP Site 801

440 is the demonstration of near-equilibrium isotope exchange between pyrite and seawater 441 sulfate at temperature below $100^{\circ} \mathrm{C}$. Extrapolating the rate law obtained for high 442 temperature experiments to $70^{\circ} \mathrm{C}$, the timescale for $90 \%$ isotope exchange between $\mathrm{SO}_{4}{ }^{2-}$ 443 and $\mathrm{H}_{2} \mathrm{~S}$, is on the order of $10^{7}$ years (Ohmoto and Lasaga, 1982; Sakai, 1983). Considering 444 that pyrite formed relatively rapidly in altered basalts due to the abundance of reactive Fe 445 for pyrite formation in altered basalt (e.g. Fe-oxyhydroxides along veins and alteration 446 halos), it is likely that the $\mathrm{H}_{2} \mathrm{~S}$ residence time is shorter than the timescale of isotope 447 exchange between $\mathrm{H}_{2} \mathrm{~S}$ and $\mathrm{SO}_{4}{ }^{2-}$. Once pyrite formed, the rate of heterogeneous isotope 448 exchange between seawater $\mathrm{SO}_{4}{ }^{2-}$ and pyrite can be considered negligible and pyrite would 449 preserve its initial $\delta^{34} \mathrm{~S}$ value. Hence, such large isotope fractionation factors in pyrite 450 reflect more likely biologically catalyzed processes (i.e. enzyme-catalyzed) rather than 451 inorganic reactions.

452 It is important to note that questions remain about the magnitude of isotope 453 fractionation during microbial sulfate reduction. Culture studies have shows a maximum 454 fractionation factor of $45 \%$ (e.g. Canfield, 2002) although fractionations as low as $2 \%$ and 455 as large as $72 \%$ have been also observed in natural samples (Chambers and Trudinger, 456 1979; Detmers et al., 2001; Wortmann et al., 2001). As proposed previously for 457 sedimentary sulfides (Canfield and Thamdrup, 1994), bacterial disproportionation of 458 intermediate $\mathrm{S}$-species is thought to be required to explain sulfide having $\delta^{34} \mathrm{~S}$ values lower 459 than $-45 \%$ with respect to sulfate (Canfield and Teske, 1996). 

determined $\delta^{34} \mathrm{~S}$ and $\Delta^{33} \mathrm{~S}$ relationships for sulfur compounds associated with dissimilatory 462 sulfate reduction, elemental sulfur disproportionation and sulfite disproportionation. These 463 studies showed that sulfide produced by sulfate reduction follows a trajectory along the 464 biological sulfate reduction line $\left({ }^{33} \alpha \approx^{34} \alpha^{0.512}\right)$ as presented in Figure 5. These studies also 465 showed that sulfite disproportionation follows a similar relationship $\left({ }^{33} \alpha \approx^{34} \alpha^{0.512}\right)$ when 466 isotope ratios of sulfide are compared with those of reactant (e.g. sulfite). According to 467 Table 2 of Johnston et al. (2005), the mass-dependent exponent ${ }^{33} \theta$ values during sulfite 468 disproportionation range from 0.5103 to 0.5107 for $D$. thiozymogenes and 0.512 for $D$. 469 sulfodismutans when ${ }^{33} \theta$ values are calculated between substrate and product pairs (i.e., 470 sulfite and sulfide) and not between two products (i.e., sulfate and sulfide). These ${ }^{33} \theta$ 471 values are within the range for sulfate reducers $\left({ }^{33} \theta\right.$ between 0.5077 to 0.5125$)$ considering 472 sulfate-sulfide pairs (Farquhar et al., 2003; Johnston et al., 2005; Johnston et al., 2007). 473 Thus, additional isotope effect associated with disproportionation of intermediate sulfur 474 species would still follow the biological fractionation line defined by sulfate reducers. 475 Using available experimental studies, it is therefore difficult to explain our data from 801C 476 that show equilibrium with seawater sulfate using available experimental studies. Different 477 environmental factors and growth conditions may result in different multiple-sulfur isotope 478 relationships between natural systems and culture experiments. In particular, pure culture 479 experiments, such as those performed by Johnston et al. (2005) are optimized for a 480 maximum growth with organic substrate in excess. In contrast, natural sulfate reducing 481 bacteria populations may frequently experience organic substrate-limitation in the 
482 environment and generally represent a higher diversity of populations which are not 483 investigated in pure culture fractionation studies.

484 Considering the putative very low metabolic activity of the deep bacterial biosphere 485 (Parkes et al., 1994; D'Hondt et al., 2002), it is likely that bacterial sulfur metabolisms in 486 altered basement proceeds at a very low rate. Hence, we tentatively interpret the 487 equilibrium S-isotope fractionation between seawater sulfate and secondary pyrite at 801 as 488 the result of bacterial sulfate reduction proceeding at very slow rate with significant back489 oxidation of sulfide due to bacterial disproportionation or abiotic reactions. Such a feature 490 may be expected for $\mathrm{S}$ metabolism that is limited by nutrient and energy availabilities, 491 consistent with endolithic communities in altered oceanic crust.

492

4.5 S-isotope budget and implication for the significance of the deep biosphere in volcanic 494 basement

Based on the analysis of the SUPER composite, the bulk altered tholeiitic section 496 recovered in Hole $801 \mathrm{C}$ yields an average $\mathrm{S}$ concentration of $0.09 \%$, which corresponds to 497 a net loss of ca. $30-40 \%$ of basaltic S during seafloor weathering (considering that S 498 concentration of the fresh crystalline $801 \mathrm{C}$ basalt section is between 0.17 and $0.12 \mathrm{wt}^{\mathrm{t}} \%$ ). 499 This confirms previous studies showing that the upper $300 \mathrm{~m}$ of the oceanic crust have 500 undergone a net depletion in S due to primary sulfide oxidation (Andrews, 1979; Alt, 501 1995). However, S-isotope composition of the SUPER composite yields negative $\delta^{34} \mathrm{~S}$ 502 values of $-6.8 \%$, suggesting significant $\mathrm{S}$ gain due to bacterial sulfate reduction that only 503 partially offsets the S loss during seafloor weathering. 
$505 \delta^{34} \mathrm{~S}$ values at around $-40 \%$ and igneous sulfides $\left(\delta^{34} \mathrm{~S}=0 \%\right.$ ), we calculate that, on 506 average, a minimum of ca. $17 \%$ of pyrite-S in altered basalts at Site 801 is derived from 507 bacterial reduction of seawater sulfate. This translates into a minimum of ca. $5 \mu \mathrm{mol} / \mathrm{g}$ of 508 seawater sulfate that is reduced and added to the crust. Using an upper crustal section of $509440 \mathrm{~m}$ of 165 Ma-old altered crust with an average density of $2.8 \mathrm{~g} / \mathrm{cm}^{3}$, we calculate a 510 minimum global flux of bacterially reduced sulfate in the upper basaltic crust of ca. $4 \times 10^{-9}$ $511 \mathrm{~mol} \mathrm{~cm}^{-2}$ year $^{-1}$. Recent estimates of subsurface microbial activity in marine sediments 512 suggest a global sulfate flux of $2.8 \times 10^{-9}$ to $13 \times 10^{-9} \mathrm{~mol} \mathrm{~cm}^{-2}$ year $^{-1}$ for sulfate-rich open513 ocean sites (D'Hondt et al., 2002). Hence, our results suggest that bacterial sulfate reduction 514 within the basaltic crust may be comparable to that in deep-seated heterotrophic systems 515 but is still at least two to three orders of magnitude lower than at ocean-margin sites.

517 sustain microbial metabolism in basaltic basement. Previous studies suggested that 518 autotrophic organisms such as Fe-oxidizers may be present in the youngest basalts formed 519 at Mid Oceanic Ridges, whereas older basalts seem to be dominated by heterotrophic 520 organisms (Thorseth et al., 2001). In addition to the potential C-sources available from 521 primary biomass production, supplemental sources of organic $\mathrm{C}$ may exist when advective 522 or diffusive exchange takes place between sediment pore waters and basalt aquifers. 523 Although the sediments at Site 801 are mostly oxidized pelagic sediments, with low organic 524 carbon content (Alt and Burdett, 1992), it is possible that a significant source of nutrient 525 and electron donors such as $\mathrm{CH}_{4}$ and $\mathrm{NH}_{4}{ }^{+}$may be transported from the overlying sediment 
526 across the sediment/basement interface (D'Hondt et al., 2004) without significant $\mathrm{H}_{2} \mathrm{~S}$

527 production in the sediments. Production of small quantities of $\mathrm{H}_{2}$ during seawater/basalt

528 interactions may also support significant autotrophic sulfate reducer communities (Bach

529 and Edwards, 2003) such as those suggested to be active during seafloor serpentinization at

530 low temperatures (Alt and Shanks, 1998). Although the nature of electron donors $\left(\mathrm{H}_{2}\right.$ or

531 organic matter) in basaltic ridge flank systems is uncertain, our results show they provide

532 an important fuel for microbial sulfate reduction.

533 We note that that no additional source of energy is needed to sustain a population of

534 S-disproportionating bacteria because only $\mathrm{CO}_{2}$ serves as a carbon source (Bak and

535 Cypionka, 1987; Cypionka et al., 1998). Bacteria able to disproportionate

536 chemolithotrophically inorganic compounds appear to be widespread in anoxic sediments

537 (Thamdrup et al., 1993) and they could be also present in basaltic environments. Because

538 several strains of sulfate reducing bacteria can also develop S disproportionation-based

539 metabolism (Cypionka et al., 1998), microbial communities in the basaltic crust could

540 potentially adapt to changing C-sources and sulfate availability.

541

542

543

544

545

546

547

548

\section{CONCLUSIONS}

Previous studies have reported ubiquitous fractionation of sulfur isotopes in altered volcanic rocks but interpretations based on abiotic fractionation between intermediate sulfur species formed during basalt alteration have been preferred. In this paper, we revisited the use of $\mathrm{S}$ isotopes as biosignatures in altered oceanic crust at ODP Site 801. In- 
549 situ ion probe $\delta^{34} \mathrm{~S}$ analyses were used to enable fine scale assessment of isotopic variations 550 in secondary sulfides and revealed highly negative $\left(\delta^{34} \mathrm{~S}\right.$ down to $-45 \%$ ) and heterogeneous $551 \quad \delta^{34} \mathrm{~S}$ values found at a depth of $834 \mathrm{~m}$ below seafloor (i.e. $340 \mathrm{~m}$ into the basement). These 552 results constitute among the clearest evidence for widespread microbial activity in basaltic 553 ocean crust. Bulk rock $\mathrm{S}$ concentrations ranging from $0.02 \%$ up to $1.28 \%$ and $\delta^{34} \mathrm{~S}$ values 554 ranging from $0.9 \%$ to $-16 \%$ are consistent with loss of magmatic primary mono-sulfide 555 and addition of secondary sulfide via microbial sulfate reduction. High-precision multiple 556 S-isotope $\left({ }^{32} \mathrm{~S},{ }^{33} \mathrm{~S},{ }^{34} \mathrm{~S}\right)$ analyses show that secondary sulfides exhibit mass-dependant 557 equilibrium fractionation relative to seawater sulfate, consistent with sulfate reduction at 558 low temperature, below $70^{\circ} \mathrm{C}$. The relationship between $\Delta^{33} \mathrm{~S}$ and $\delta^{34} \mathrm{~S}$ values suggests that 559 bacterial sulfate reduction proceeds at very low metabolic rates. Finally, the determination 560 of the S-isotope composition of bulk altered oceanic crust demonstrates that S-based 561 metabolic activity of subsurface life in oceanic basalt is widespread, and can affect the 562 global S budget in oceanic crust.

563 Although it is possible that secondary pyrite at Site 801 may form during protracted 564 periods, probably up to $50 \mathrm{Ma}$ after crust formation of ridge axis, additional work is 565 required to better constraints the timing of microbial activity. Microbial communities that 566 colonize the basaltic surface layer at mid-oceanic ridges may become buried below several 567 hundred meters during seafloor spreading and aging of the oceanic crust, but could also 568 enter the basement during fluid exchange with overlying sediments as the crust is buried. 569 Identifying and culturing these widespread deep-endolithic microorganisms in igneous 570 oceanic basement may provide a unique opportunity to test the metabolic limit of microbial 
571 life, its relationship with the subsurface biosphere in sediments and its role in affecting 572 chemical exchange between the ocean and lithosphere. 
575 The technical help of Michel Champenois on ion microprobe is gratefully acknowledged.

576 We thank Luc Marin for S concentration analyses. Ion-probe and chemical analysis have 577 been supported by INSU-CNRS. Alt's contribution was supported by NSF OCE-0424558 578 and OCE-0622949. Rouxel's contribution was supported by NSF OCE-0622982 and Frank 579 and Lisina Hoch Endowed Fund. Ono thanks Agouron Institute and NSF OCE-0753126 for 580 funding. This research used samples and/or data provided by the Ocean Drilling Program. 581 The ODP is sponsored by the US National Science Foundation (NSF) and participating 582 countries under the management of Joint Oceanographic Institutions (JOI). The work 583 benefited from fruitful discussions and comments by W. Bach, K. Edwards, J. Hayes and T. 584 Lyons, B. Wing and two anonymous reviewers. 


\section{REFERENCES CITED}

Alt, J.C., 1995. Sulfur isotopic profile through the oceanic crust: Sulfur mobility and seawater-crustal sulfur exchange during hydrothermal alteration. Geology, 23: 585588.

Alt, J.C. and Burdett, J.W., 1992. Sulfur in pacific deep-sea sediments (leg 129) and implications for cycling of sediment in subduction zones. In: R.L. Larson and Y. Lancelot (Editors), Proc. ODP, Sci. Res. 129. Ocean Drilling Program, College Station, TX, pp. 283-294.

Alt, J.C., Davidson, G.J., Teagle, D.A.H. and Karson, J.A., 2003. Isotopic composition of gypsum in the Macquarie Island ophiolite: Implications for the sulfur cycle and the subsurface biosphere in oceanic crust. Geology. 31, 549-552.

Alt, J.C. and Shanks, W.C., 1998. Sulfur in serpentinized oceanic peridotites: Serpentinization processes and microbial sulfate reduction. J. Geophys. Res., 103, 9917-9929.

Alt, J.C. and Teagle, D.A.H., 1999. The uptake of carbon during alteration of ocean crust. Geochim. Cosmochim. Acta, 63, 1527-1535.

Alt, J.C. and Teagle, D.A.H., 2003. Hydrothermal alteration of upper oceanic crust formed at a fast-spreading ridge: mineral, chemical, and isotopic evidence from ODP Site 801. Chem. Geol., 201, 191-211.

Andrews, A.J., 1979. On the effect of low-temperature seawater interaction on the distribution of sulfur in oceanic crust, layer 2. Earth Planet. Sci. Lett., 46, 68-80.

Bach, W. and Edwards, K.J., 2003. Iron and sulfide oxidation within the basaltic ocean crust: Implications for chemolithoautotrophic microbial biomass production. Geochim. Cosmochim. Acta, 67, 3871-3887.

Bak, F. and Cypionka, H., 1987. A novel type of energy metabolism involving fermentation of inorganic compounds. Nature, 326, 891-892.

Canfield, D.E., 2002. Biogeochemistry of sulfur isotopes. In: J.W. Valley and D.R. Cole (Editors), Stable isotope geochemistry: Mineralogical Society of America. Reviews in Mineralogy, pp. 607-633.

Canfield, D.E., Raiswell, R., Westrich, J.T., Reaves, C.M. and Berner, R.A., 1986. The use of chromium reduction in the analysis of reduced inorganic sulfur in sediments and shales. Chem. Geol. 54, 149-155.

Canfield, D.E. and Teske, A., 1996. Late Proterozoic rise in atmospheric oxygen concentration inferred from phylogenetic and sulphur-isotope studies. Nature. 382, 127-132.

Canfield, D.E. and Thamdrup, B., 1994. The production of 34S depleted sulfide during bacteial disproportionation of elemental sulfur. Science, 266, 1973-1975.

Chambers, L.A. and Trudinger, P.A., 1979. Microbiological fractionation of stable sulfur isotopes: a review and critique. Geomicrobiol. J., 1, 249-293.

Chaussidon, M. and Demange, J.C., 1988. Instrumental mass fractionation in ion microprobe studies of sulphur isotopic ratios. In: A. Benninghoven, A.M. Huber and H.W. Werner (Editors), Secondary Ion Mass Spectrometry VI. John Wiley Sons, New York, pp. 937-940. 
Chu, X., Ohmoto, H. and Cole, D.R., 2004. Kinetics of sulfur isotope exchange between aqueous sulfide and thiosulfate involving intra- and intermolecular reactions at hydrothermal conditions. Chem. Geol., 211, 217-235.

Claypool, G.C., Holser, W.T., Kaplan, I.R., Sakai, H. and Zak, I., 1980. The age curves of sulfur and oxygen isotopes in marine sulfate and their mutual interpretations. Chem. Geol., 28, 199-260.

Coplen, T.B. and Krouse, H.R., 1998. Sulphur isotope data consistency improved. Nature, $392,32$.

Cypionka, H., Smock, A. and Böttcher, M.E., 1998. A combined pathway of sulfur compound disproportionation in Desulfovibrio desulfuricans. FEMS Microbiol. Lett, 166, 181-186.

D'Hondt, S., Jorgensen, B.B., Miller, D.J. and etal, 2004. Distributions of Microbial Activities in Deep Subseafloor Sediments. Science, 306, 2216-2221.

D'Hondt, S., Rutherford, S. and Spivack, A., 2002. Metabolic Activity of Subsurface Life in Deep-Sea Sediments. Science, 295, 2067-2070.

Detmers, J., Bruchert, V., Habicht, K.S. and Kuever, J., 2001. Diversity of sulfur isotope fractionation by sulfate-reducing prokaryotes. Appl. Environ. Microbiol., 67, 888894.

Farquhar, J. et al., 2003. Multiple sulphur isotopic interpretations of biosynthetic pathways; implications for biological signatures in the sulphur isotope record. Geobiology, 1, 27-36.

Field, C.W., Dymond, J.R., Heath, G.R., Corliss, J.B. and Dasch, E.J., 1976. Sulfur isotope reconnaissance of epigenetic pyrite in ocean-floor basalts, Leg 34 and elsewhere, Initial Reports of the DSDP, vol. 34, pp. 381-384.

Fisk, M. and Kelley, K., 2002. Probing the Pacific's oldest MORB glass: mantle chemistry and melting conditions during the birth of the Pacific Plate. Earth Planet. Sci. Lett., 202, 741-752.

Fisk, M.R., Giovannoni, S.J. and Thorseth, I.H., 1998. Alteration of oceanic volcanic glass: textural evidence of microbial activity. Science, 281, 978-980.

Furnes, H., Muehlenbachs, K., Torsvik, T., Thorseth, I.H. and Tumyr, O., 2001. Microbial fractionation of carbon isotopes in altered basaltic glass from the Atlantic Ocean, Lau Basin and Costa Rica Rift. Chemical Geology, 173, 313-330.

Gao, X. and Thiemens, M.H., 1991. Systematic study of sulfur isotopic composition in iron meteorites and the occurrence of excess $33 \mathrm{~S}$ and $36 \mathrm{~S}$. Geochim. Cosmochim. Acta, 55, 2671-2679.

Govindaraju, K. and Mevelle, G., 1987. Fully automated dissolution and separation methods for inductively coupled plasma-atomic emission spectrometry rock analysis. Apllication to the determination of rare earth elements. J. Anal. Atom. Spectro., 2, 615-621.

Habicht, K.S., Canfield, D.E. and Rethmeier, J., 1998. Sulfur isotope fractionation during bacterial reduction and disproportionation of thiosulfate and sulfite. Geochim. Cosmochim. Acta, 62, 2585-2595.

Hu, G.X., Rumble, D. and Wang, P.L., 2003. An ultraviolet laser microprobe for the insitu analysis of multisulfur isotopes and its use in measuring Archean sulfur isotope mass-independent anomalies. Geochim. Cosmochim. Acta, 67, 3101-3118. 
Hulston, J.R. and Thode, H.G., 1965. Variations in the S33, S34, and S36 contents of meteorites and their relation to chemical and nuclear effects. J. Geophys. Res., 70, 3475-3484.

Johnston, D.T., Farquhar, J. and Canfield, D.E., 2007. Sulfur isotope insights into microbial sulfate reduction: When microbes meet models. Geochim. Cosmochim. Acta, 71, 3929-3947.

Johnston, D.T. et al., 2005. Multiple sulfur isotope fractionations in biological systems: a case study with sulfate reducers and sulfur disproportionators. Am. J. Sci., 305, 645660.

Jorgensen, B.B., 1990. A thiosulfate shunt in the sulfur cycle of marine sediments. Science, 249, 152-154.

Kelley, K.A., Plank, T., Ludden, J. and Staudigel, H., 2003. Composition of altered oceanic crust at ODP Sites 801 and 1149. Geochem. Geophys. Geosys., 4, doi:10.1029/2002GC000435.

Koppers, A.A.P., Staudigel, H. and Duncan, R.A., 2003. High-resolution 40Ar/39Ar dating of the oldest oceanic basement basalts in the western Pacific basin. Geochem. Geophys. Geosyst., 4, doi: 10.1029/2003GC000574.

Krouse, H.R., Brown, H.M. and Farquharson, R.B., 1977. Sulphur isotope compositions of sulphides and sulphates, DSDP Leg 37. Can. J. Earth Sci., 14, 787-793.

Larson, R.L., Lancelot, Y. and ShipboardScientificParty, 1992. Proc. ODP, Sci. Results, 129, CollegeStation, TX.

Miller, M.F., 2002. Isotopic fractionation and the quantification of 170 anomalies in the oxygen three-isotope system; an appraisal and geochemical significance. Geochim. Cosmochim. Acta, 66, 1881-1889.

Moore, J.G. and Fabbi, B.P., 1971. An estimate of the juvenile sulfur content of basalt. Contrib. Mineral. Petrol., 41, 105-118.

Ohmoto, H. and Lasaga, A.C., 1982. Kinetics of reactions between aqueous sulfates and sulfides in hydrothermal systems. Geochim. Cosmochim. Acta, 46, 1727-1745.

Ono, S., ShanksIII, W.C., Rouxel, O.J. and Rumble, D., 2007. Multiple-sulfur isotope constraints on the seawater sulfate contribution in modern seafloor hydrothermal sulfide. Geochem. Cosmochim. Acta, 71, 1170-1182.

Ono, S., Wing, B.A., Johnston, D., Farquhar, J. and Rumble, D., 2006. Mass-dependent fractionation of quadruple sulfur isotope system as a new tracer of sulfur biogeochemical cycles. Geochim. Cosmochim. Acta, 70, 2238-2252.

Parkes, R.J. et al., 1994. Deep bacterial biosphere in Pacific Ocean sediments. Nature, 371, 410-413.

Plank, T., Ludden, J.N., Escutia, C. and am, e., 2000. Proc. ODP, Init Repts., 185, College Station (TX).

Pockalny, R.A. and Larson, R.L., 2003. Implications for crustal accretion at fast spreading ridges from observations in Jurassic oceanic crust in the western Pacific. Geochem. Geophys. Geosyst., 4, doi:10.1029/2001GC000274.

Pringle, M., 1992. Radiometric ages of basaltic basement recovered at Sites 800, 801, and 802, Leg 129, western Pacific Ocean. In: Y.L. R.L. Larson, A. Fisher and E.L. Winterer (Editor), Proc. Ocean Drill. Program, Sci. Results, 129. Ocean Drilling Program, Texas A\&M University, College Station,, pp. 389-404. 
Puchelt, H., Prichard, H.M., Berner, Z. and Maynard, J., 1996. Sulfide mineralogy, sulfur content, and sulfur isotope composition of mafic and ultramafic rocks from Leg 147. Proceedings of the Ocean Drilling Program, Scientific Results : College Station, TX (Ocean Drilling Program), 147, 91-101.

Reisberg, L., Rouxel, O., Ludden, J., Staudigel, H. and Zimmermann, C., 2007. Re-Os results from ODP Site 801: Evidence for extensive Re uptake during alteration of oceanic crust. Chem. Geol. (in press).

Revillon, S., Barr, S.R., Brewer, T.S., Harvey, P.K. and Tarney, J., 2002. An alternative approach using integrated gamma-ray and geochemical data to estimate the inputs to subduction zones from ODP Leg 185, Site 801. Geochem. Geophys. Geosys., 3, doi: 10.1029/2002GC000344.

Rice, C.A., Tuttle, M.L. and Reynolds, R.L., 1993. The analysis of forms of sulfur in ancient sediments and sedimentary rocks: comments and cautions:. Chemical Geology, 107, 83-95.

Sakai, H., 1983. Sulfur isotope exchange rate between sulfate and sulfide and its application. Geothermics, 12, 111-117.

Sakai, H. and Dickson, F.W., 1978. Experimental determination of the rate and equilibrium fractionation factors of sulfur isotope exchange between sulfate and sulfide in slightly acid solutions at $300^{\circ} \mathrm{C}$ and 1000 bars. Earth Planet. Sci. Lett., 30, 151-161.

Staudigel, H., 2003. Hydrothermal Alteration Processes. In: H. Holland and K. Turekian (Editors), Treatise of Geochemistry, pp. 511-537.

Staudigel, H. and Hart, S.R., 1983. Alteration of basaltic glasses: Mechanisms and significance for the oceanic crust-seawater budget. Geochim. Cosmochim. Acta, 47, 337-350.

Talbi, E.H. and Honnorez, J., 2003. Low-temperature alteration of Mesozoic oceanic crust, ODP Leg 185. Geochem. Geophys. Geosys., 4, doi:10.1029/2002GC000405.

Thamdrup, B., Finster, K., Hansen, W. and Bak, F., 1993. Bacterial disproportionation of elemental sulfur coupled to chemical reduction of iron and manganese. Appl. Environ. Microbiol, 59, 101-108.

Thorseth, I.H., Furnes, H. and Heldal, M., 1992. The importance of microbiological activity in the alteration of natural basaltic glass. Geochim. Cosmochim. Acta, 56, 845-850.

Thorseth, I.H., Torsvik, T., Torsvik, V., Daae, F.L. and Pedersen, R.B., 2001. Diversity of life in ocean floor basalt. Earth Planet. Sci. Lett., 194, 31-37.

Uyama, F., Chiba, H., Kusakabe, M. and Sakai, H., 1985. Sulfur isotope exchange reactions in the aqueous system: Thiosulfate-sulfide-sulfate at hydrothermal temperature. Geochem. J., 19, 301-315.

Wortmann, U.G., Bernasconi, S.M. and Bottcher, M.E., 2001. Hypersulfidic deep biosphere indicates extreme sulfur isotope fractionation during single-step microbial sulfate reduction. Geology, 29, 647-650.

Young, E.D., Galy, A. and Nagahara, H., 2002. Kinetic and equilibrium mass-dependent isotope fractionation laws in nature and their geochemical and cosmochemical significance. Geochim. Cosmochim. Acta, 66, 1095-1104.

Zhang, J.-Z. and Millero, F.J., 1993. The products from the oxidation of H2S in seawater. Geochim. Cosmochim. Acta, 57, 1705-1718. 
765 


\section{Figure Captions}

Figure 1. Map of the West Pacific (Izu and Mariana arcs) and location of ODP Hole 801C drilled during Leg 129 and 185. Modified after Plank et al. (2000).

Figure 2. Downhole $\delta^{34} \mathrm{~S}$ composition of sulfides in Hole 801C. Simplified stratigraphic column of basaltic basement is shown with the depth scale. S-isotope compositions obtained by ion-microprobe for individual pyrite and marcasite minerals are marked by crosses while pyrite separates analyzed for multiple S-isotopes and conventional gas-source mass spectrometers are marked by gray and black circles respectively. Gray and black diamonds correspond to bulk rock $\mathrm{S}$ isotope analysis for AVS and Cr-S respectively. Dashed vertical line represents the $\mathrm{S}$ isotope composition of fresh basalts. H.D = Si-Fe-rich hydrothermal deposit. ALK $=$ Alkaline basalts. $\mathrm{MORB}=$ mid-ocean ridge basalts. Error bars for ion microprobe is 2 per mil whereas the error bars on the gray and black symbols are 0.2 per mil.

Figure 3. photomicrograph of pyrite and marcasite analysed by ion microprobe with corresponding $\delta^{34} \mathrm{~S}$ values. (a) $801 \mathrm{C}-43 \mathrm{R} 1,29 / \mathrm{v}$; large polycrystalline aggregate of marcasite in 2cm thick carbonate vein; (b) 801C-6R5,75; pyrite lining carbonate-rich vein; (c) sample 801C-9R1,32; marcasite enrichment in alteration halo; (d) 801C-17R1,100; pyrite in thin vein associated with saponite; (e) 801C-23R1,45; pyrite enrichment in basalt 
associated with vesicles filled with carbonate; (f) 801C-27R1,50; pyrite-rich patch within microdolerite with titanomagnetite needles intergrowth.

Figure 4. Plot of $\mathrm{S}$ concentration versus $\mathrm{S}$ isotope composition of whole altered basalts at Site 801 (diamonds). The SUPER composite, representative of the bulk altered crust at Site 801 and fresh basalt are plotted for comparison. Arrows represent schematic trends. Curves (a) and (b) represent mixing lines between fresh basalt and secondary sulfides formed through dissimilatory sulfate reduction with fractionation factors of 1.025 and 1.045 respectively. Curve (c) represents possible evolutions of $\mathrm{S}$ concentration and $\delta^{34} \mathrm{~S}$ values during partial oxidation of igneous sulfides proceeding through disproportionation reactions and following a Rayleigh-type fractionation process (fractionation factor between forming $\mathrm{SO}_{4}{ }^{2-}$ and intermediate S-species is taken at 1.013 after Canfield and Thamdrup (1994)). Curve (d) represents the trend for primary sulfide dissolution (i.e. quantitative leaching).

Figure 5. $\delta^{34} \mathrm{~S}$ vs. $\Delta^{33} \mathrm{~S}$ and $\delta^{34} \mathrm{~S}^{*}$ vs. $\Delta^{33} \mathrm{~S}^{*}$ compositions of secondary sulfides from Site 801 compared with sedimentary biogenic sulfides (Ono et al., 2006) and hydrothermal pyrite from mid-ocean ridges (Ono et al., 2007). MORB=Mid-Ocean Ridge Basalt, estimated from the analysis of Canyon Diablo Troilite (CDT) which is representative of primordial sulfur in fresh mid-ocean ridge basalt (Ono et al., 2007). SW = modern to Jurassic seawater determined by the analysis of carbonate-associated sulfate (Ono and Lyons, unpub results) and modern marine sulfate (Ono et al., 2007). Various examples of mixing lines between igneous $\mathrm{S}$ and secondary sulfides from Site 801 are plotted. The 
809 isotope composition of $\mathrm{H}_{2} \mathrm{~S}$ in isotope equilibrium with seawater $\mathrm{SO}_{4}{ }^{2-}(\mathrm{SW})$ as a function 810 of temperature is described by the solid black line (after Ono et al., 2007). The isotope 811 composition of $\mathrm{H}_{2} \mathrm{~S}$ produced by bacterial sulfate reduction using fractionation lines 812 experimentally determined by Farquhar et al. (2003) is also shown for comparison.

813

814

815

816 


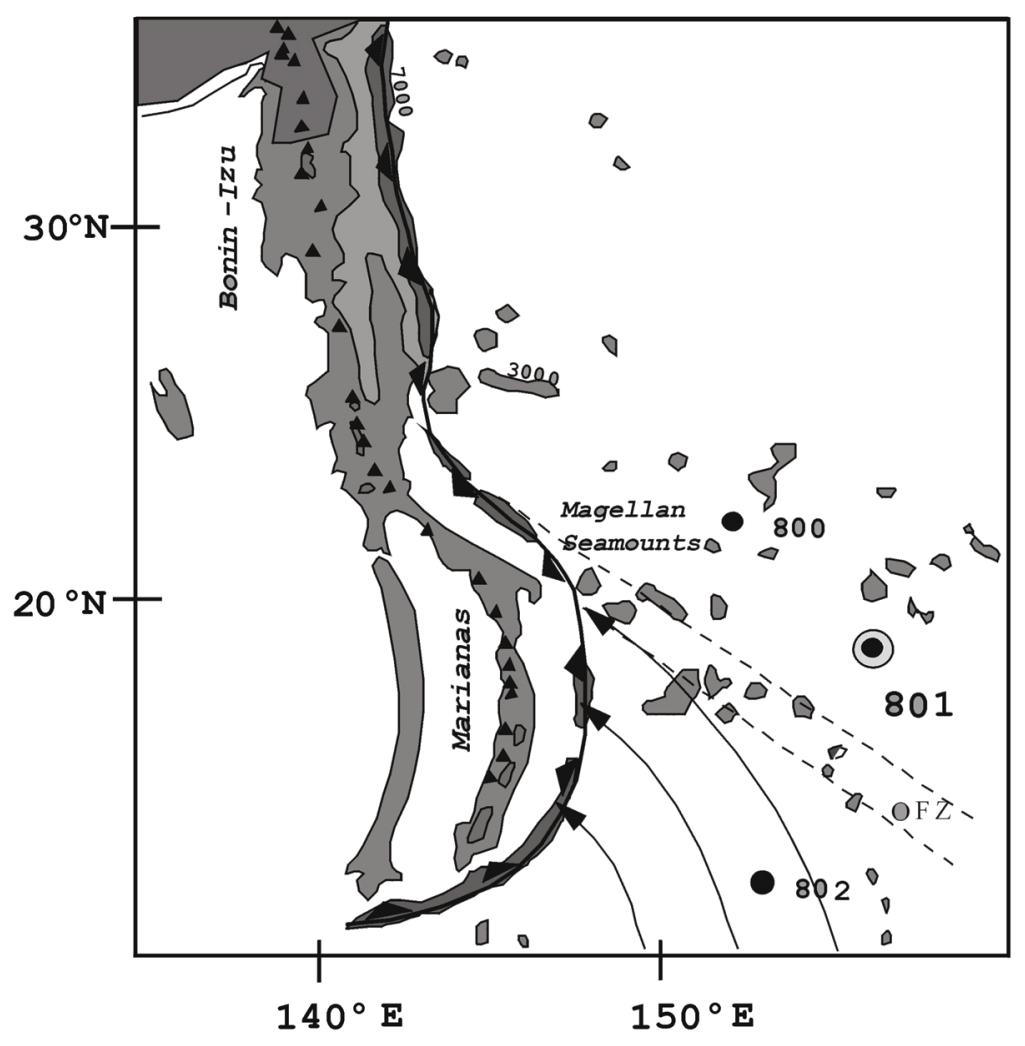

Figure 1 


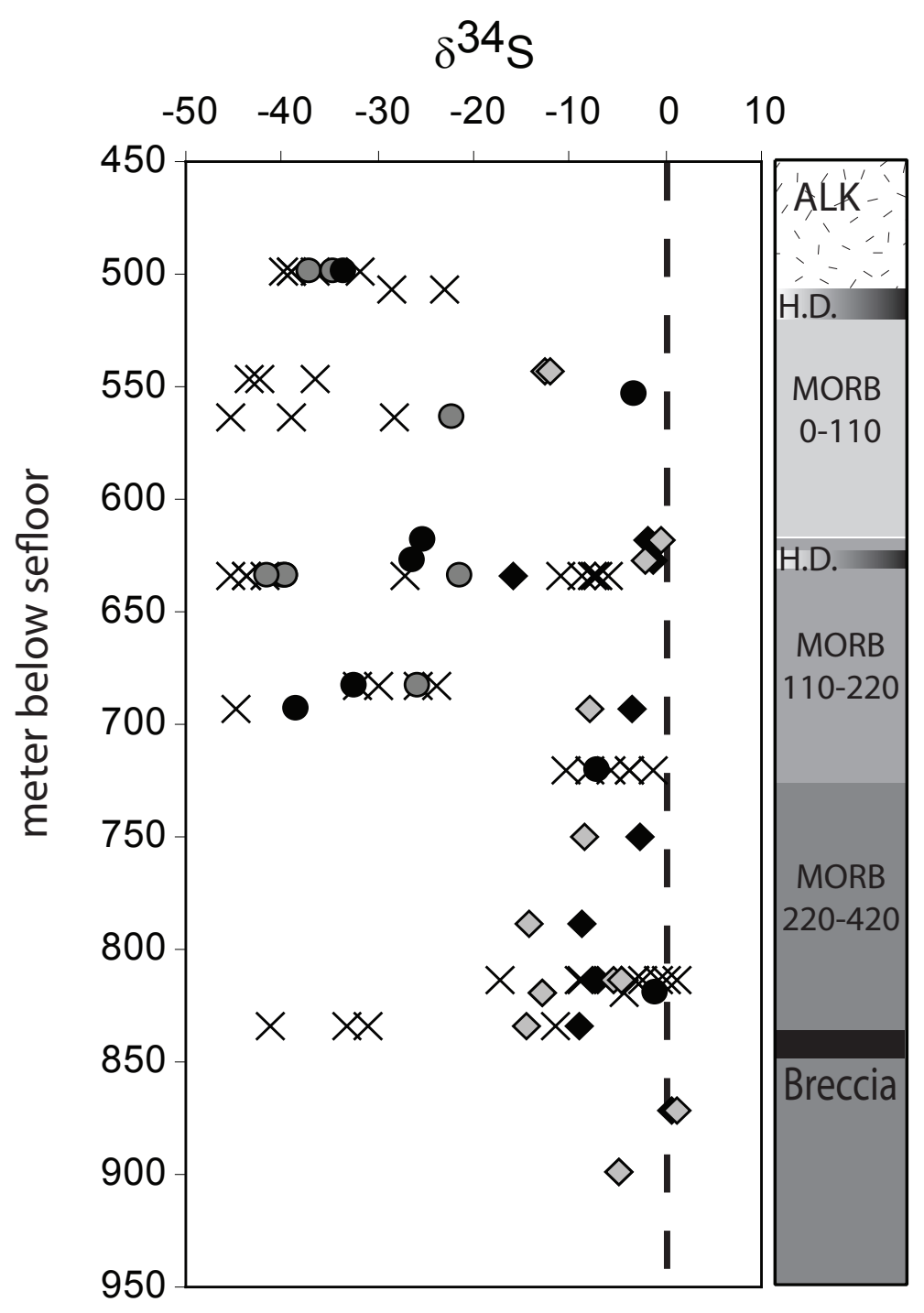

Figure 2 

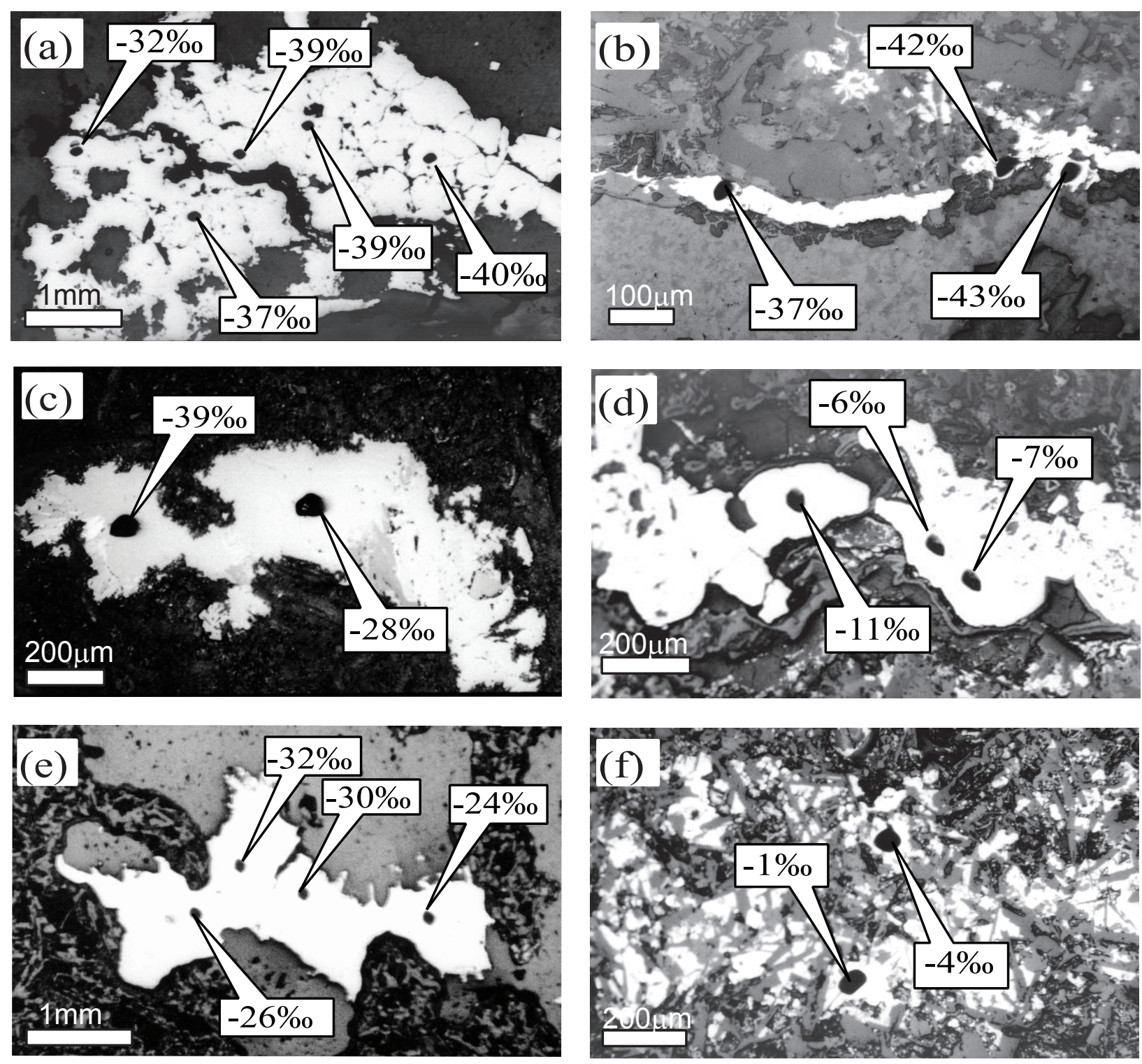

Figure 3 


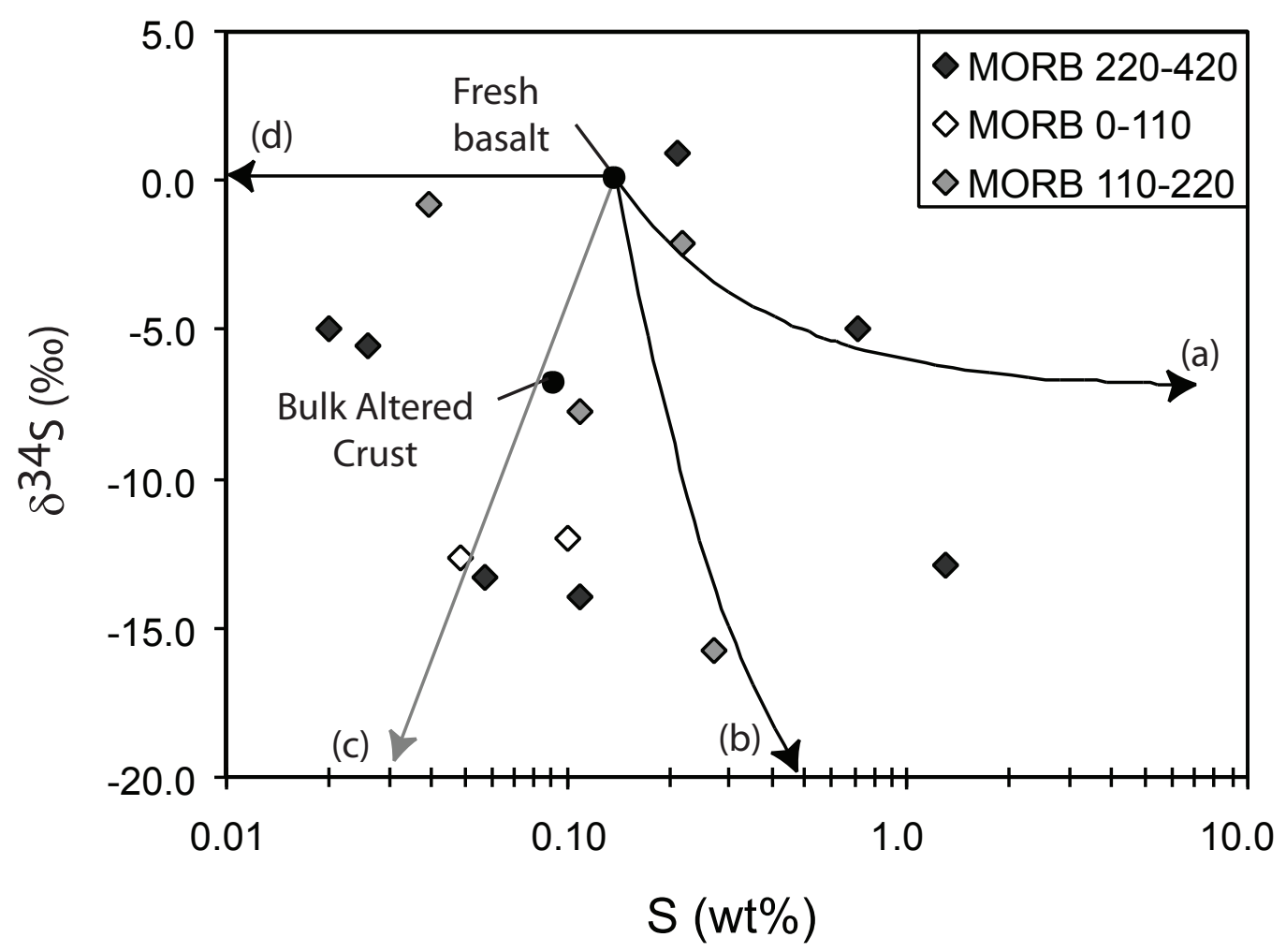

Figure 4 

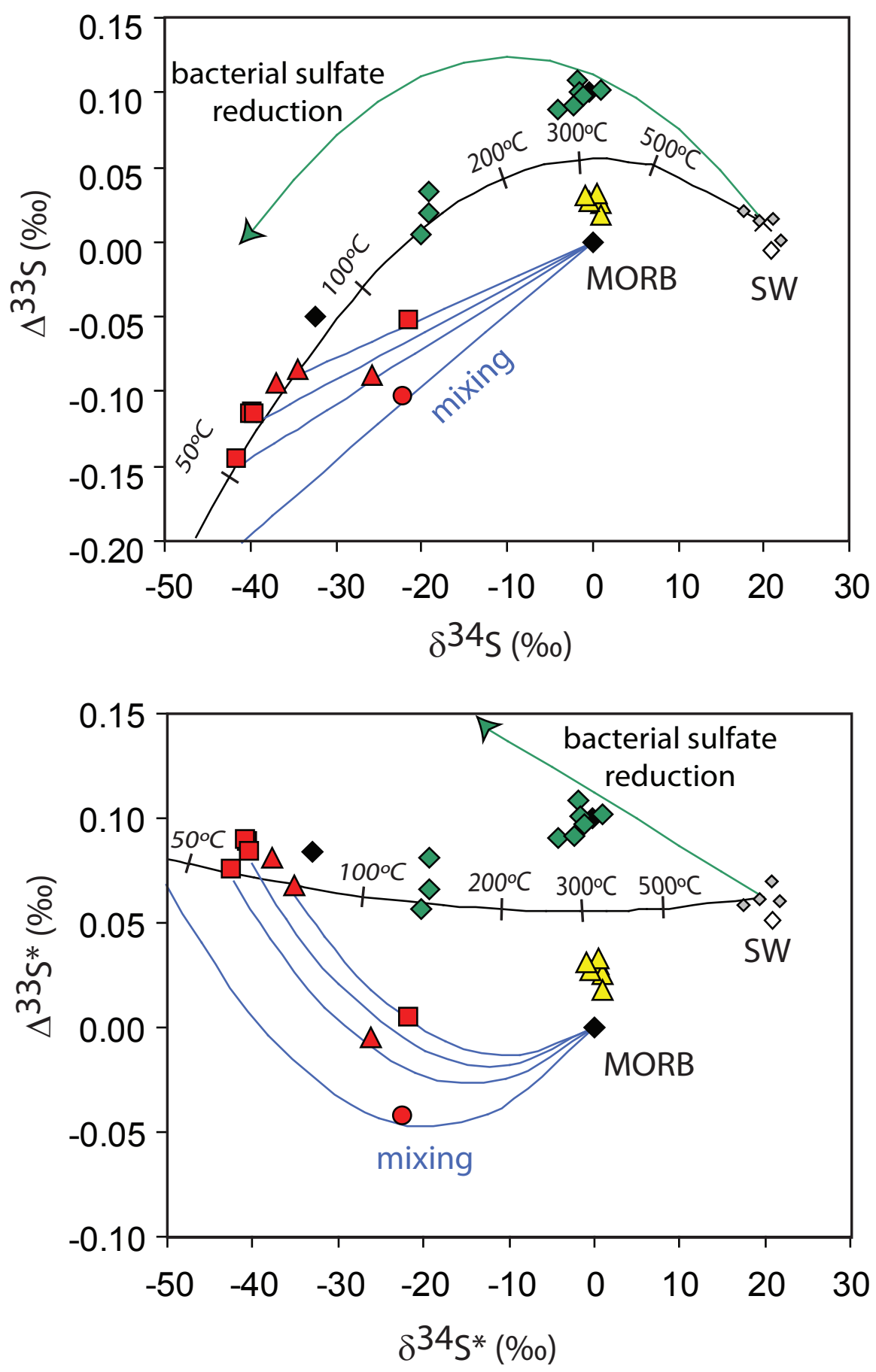

$\begin{array}{ll}\triangle \text { Hydrothermal pyrite } & \text { O 801C-9R1 } \\ \diamond \text { Biogenic pyrite } & \square \text { 801C-17R1 } \\ \diamond \text { Modern seawater } & \triangle 801 C-43 R 1 \\ \diamond \text { Jurassic seawater } & \end{array}$

Figure 5 
Table 1: Major element chemistry, S concentration and S-isotope composition of altered basalts at Site 801

\begin{tabular}{|c|c|c|c|c|c|c|c|c|c|c|c|c|c|c|c|c|c|c|c|}
\hline Sample & Depth & LOI & $\mathrm{Al}_{2} \mathrm{O}_{3}$ & $\mathrm{CaO}$ & $\mathrm{Fe}_{2} \mathrm{O}_{3} \mathrm{~T}$ & $\frac{\mathrm{K}_{2} \mathrm{O}}{(}$ & $\frac{\mathrm{MgO}}{\mathrm{wt} \%)}$ & $\mathrm{MnO}$ & $\mathrm{Na}_{2} \mathrm{O}$ & $\mathrm{P}_{2} \mathrm{O}_{5}$ & $\mathrm{SiO}_{2}$ & $\mathrm{TiO}_{2}$ & $\begin{array}{c}\Sigma \mathrm{S} \\
(w t \%)\end{array}$ & $\begin{array}{c}\delta^{34} \mathrm{~S} \\
\Sigma \mathrm{S}\end{array}$ & $\begin{array}{c}\mathrm{CrS} / \Sigma \mathrm{S}^{*} \\
(\%)\end{array}$ & $\begin{array}{l}\delta^{34} S \\
\text { AVS }\end{array}$ & $\begin{array}{l}\delta^{34} \mathrm{~S} \\
\mathrm{CrS}\end{array}$ & $\begin{array}{l}\delta^{34} \mathrm{~S} \\
\mathrm{SO} 4\end{array}$ & Description \\
\hline 801C-06R3,18 & 543 & 6.4 & 22.1 & 8.0 & 3.6 & 2.6 & 1.7 & $<0.05$ & 2.72 & 0.07 & 51.6 & 1.19 & 0.100 & -12.0 & 97.3 & & -12.0 & -5.6 & Highly altered aphyric basalt \\
\hline 801C-06R3,42 & 544 & 9.9 & 21.9 & 14.1 & 6.0 & 0.8 & 2.4 & 0.15 & 3.04 & 0.07 & 50.0 & 1.14 & 0.049 & -12.7 & 79.5 & & -12.7 & -6.0 & $\begin{array}{l}\text { Medium altered basalt with } \\
\text { carbonate veins }\end{array}$ \\
\hline 801C-15R4,69 & 618 & 4.7 & 14.8 & 11.0 & 12.6 & 0.1 & 5.7 & 0.16 & 2.79 & 0.20 & 46.1 & 1.85 & 0.039 & -0.8 & 74.0 & -1.9 & -0.4 & & $\begin{array}{l}\text { Medium altered basalt with thin } \\
\text { saponite veins }\end{array}$ \\
\hline $801 C-15 R 7,1$ & 621 & 7.1 & 19.5 & 8.2 & 5.5 & 0.9 & 1.5 & 0.03 & 3.65 & 0.20 & 51.0 & 2.44 & 0.051 & & & & & & Highly altered (bleached) basalt \\
\hline 801C-15R7,31 & 622 & 9.9 & 18.4 & 12.9 & 5.1 & 0.5 & 1.8 & 0.13 & 3.44 & 0.24 & 46.1 & 2.17 & 0.082 & & & & & & Highly altered (bleached) basalt \\
\hline $801 C-16 R 3,82$ & 627 & 8.3 & 16.6 & 6.2 & 12.1 & 0.5 & 2.5 & 0.10 & 3.19 & 0.38 & 45.3 & 3.78 & 0.220 & -2.1 & 94.9 & -1.4 & -2.2 & -2.5 & Highly altered basalt \\
\hline 801C-17R1,100 & 634 & 3.1 & 12.7 & 11.3 & 15.9 & 0.1 & 5.5 & 0.26 & 2.53 & 0.28 & 46.1 & 2.71 & 0.270 & -15.8 & 18.0 & -15.8 & & -2.9 & $\begin{array}{l}\text { Least altered basalt with pyrite and } \\
\text { carbonate-filled vesicules }\end{array}$ \\
\hline $801 C-24 R 2,36$ & 693 & 1.7 & 13.7 & 11.3 & 14.7 & 0.1 & 6.6 & 0.26 & 2.60 & 0.24 & 47.2 & 2.14 & 0.110 & -7.7 & 95.7 & -3.4 & -7.9 & -7.9 & Least altered aphyric basalt \\
\hline $801 C-25 R 1,10$ & 701 & 1.7 & 13.7 & 11.7 & 14.1 & 0.0 & 6.9 & 0.25 & 2.68 & 0.2 & 48.6 & 2.0 & 0.016 & & & & & & Least altered aphyric basalt \\
\hline 801C-34R3,81 & 789 & 3.4 & 12.9 & 9.4 & 16.2 & 0.7 & 5.3 & 0.18 & 2.59 & 0.22 & 46.7 & 2.33 & 0.057 & -13.3 & 85.6 & -8.8 & -14.1 & -5.2 & $\begin{array}{l}\text { Medium altered basalt with alteration } \\
\text { halos }\end{array}$ \\
\hline 801C-37R1,83 & 814 & 3.5 & 13.3 & 10.5 & 13.7 & 0.1 & 6.0 & 0.22 & 2.65 & 0.25 & 47.5 & 2.34 & 0.720 & -4.9 & 84.2 & -7.2 & -4.5 & -3.9 & $\begin{array}{l}\text { Least altered basalt with carbonate } \\
\text { and saponite-filled vesicules }\end{array}$ \\
\hline 801C-37R1,83/V & 814 & 10.8 & 6.2 & 2.0 & 46.8 & 0.5 & 4.8 & 0.07 & 0.47 & 0.11 & 27.5 & 1.02 & 0.026 & -5.5 & & & -5.5 & 1.2 & $\begin{array}{l}\text { Large celadonite and Fe-oxide vein } \\
\text { with carbonate }\end{array}$ \\
\hline 801C-37R5,30 & 819 & 1.6 & 13.1 & 10.0 & 13.5 & 0.2 & 5.0 & 0.22 & 2.83 & 0.19 & 50.9 & 2.37 & 1.300 & -12.9 & 47.4 & -12.9 & -12.9 & -8.0 & Least altered basalt \\
\hline 801C-39R2,28 & 834 & 1.9 & 13.8 & 10.8 & 14.2 & 0.1 & 6.9 & 0.27 & 2.62 & 0.23 & 46.8 & 2.34 & 0.110 & -14.0 & 90.2 & -9.0 & -14.5 & -1.9 & Least altered aphyric basalt \\
\hline 801C-43R1,13 & 869 & 2.2 & 13.5 & 11.0 & 13.3 & 0.1 & 6.4 & 0.23 & 2.78 & 0.18 & 48.5 & 2.00 & 0.410 & & & & & & Least altered basalt \\
\hline $801 C-43 R 2,75$ & 871 & 0.3 & 14.6 & 10.7 & 12.7 & 0.2 & 6.5 & 0.22 & 3.02 & 0.26 & 48.6 & 2.10 & 0.210 & 0.9 & 29.5 & 0.8 & 1.3 & -0.8 & Least altered basalt with thin veins \\
\hline 801C-46R1,106 & 899 & 1.6 & 13.9 & 11.3 & 13.2 & 0.1 & 7.1 & 0.21 & 2.57 & 0.2 & 47.7 & 2.0 & 0.020 & -5.0 & 61.4 & -5.0 & -5.0 & & Least altered basalt \\
\hline $801 \mathrm{C}-52 \mathrm{M} 1,47$ & 933 & 1.8 & 13.7 & 11.5 & 14.4 & 0.1 & 7.4 & 0.27 & 2.85 & 0.2 & 48.5 & 2.3 & 0.014 & & & & & & Least altered basalt \\
\hline 801 SUPER & 750 & 7.7 & 11.1 & 12.0 & 12.7 & 0.6 & 5.7 & 0.21 & 2.12 & 0.15 & 45.4 & 1.54 & 0.092 & -6.8 & 72.0 & -2.7 & -8.4 & -3.8 & Composite \\
\hline
\end{tabular}

* $\mathrm{CrS} / \Sigma \mathrm{S}$ corresponds to the proportion (in \%) of Cr-reducible S (pyrite) relative to total S measured 
Table 2: Individual $\delta^{34} S$ analysis of secondary sulfides in Hole 801C

Sample Description
$\mathbf{8 0 1 B - 4 3 R 1 , 2 9 - 4 9 9 . 4 ~ m b s f}$
mar-1*
mar-2\#1
mar-2\#2 marcasite aggregate with minor pyrite
mar-3\#1 vein (5mm thick)
mar-3\#2
mar-3\#3

\section{C-2R3,59 - 506.4 mbsf}

py-1\#1 Dissiminated pyrite grain $(0.5 \mathrm{~mm})$ in py-1\#2 carbonate rich vein ( $2 \mathrm{~mm}$ thick)

801C-06R5,75 - 546.9 mbsf

py-1\#1 pyrite veinlet (0.5mm thick) lining a

py-1\#2 arbonate-rich vein (2mm thick),

occurrence of pyrite aggregates

py-1\#3 locally

801C-07R2,132 - 552.9 mbsf

py-1\#1 pyrite veinlet $(0.1 \mathrm{~mm}$ thick) lining a

801C-09R1,32 - 563.5 mbsf

py-1\#1 polycrystalline marcasite aggregate

py-1\#2 dissiminated in basalt groundmass

py-2\#3 ditto, $2 \mathrm{~mm}$ from py-1

801C-15R4,69 - 618.3 mbsf

hand-picked pyrite grains from

py-1* carbonate and saponite-rich vein (3mm thick)

801C-16R4,9 - 627.5 mbsf

py-1* hand-picked pyrite grains from saponite-rich vein ( $2 \mathrm{~mm}$ thick)

\section{C-17R1,100 - 633.8 mbsf}

py-1\#1

pyrite grains dissiminated along

py-1\#3 minor carbonate and saponite

py-2\#1 ditto, $1 \mathrm{~mm}$ from py-1 along vein

py-3\#1 ditto, $0.5 \mathrm{~mm}$ from py-2 along vein

py-4\#1

py-4\#2

ditto, $0.2 \mathrm{~mm}$ from py-3 along vein

py-5\#1 ditto, $1 \mathrm{~mm}$ from py-4 along vein

py-6\#1 pyrite grain within basalt groudmass

py-7\#1 pyrite grain within basalt groudmass

py-8\#1 ditto
Table 2 (continued)

\begin{tabular}{|c|c|c|}
\hline Sample & Description & $\delta^{34} \mathrm{~S}$ \\
\hline \multicolumn{3}{|c|}{ 801C-23R1,45 - 682.4 mbsf } \\
\hline py-1* & \multirow{5}{*}{$\begin{array}{l}\text { local pyrite enrichment (polycrystalline } \\
\text { aggregates) associated with carbonate- } \\
\text { rich vesicules (1-3mm wide) }\end{array}$} & -32.5 \\
\hline py-2\#1 & & -25.7 \\
\hline py-2\#2 & & -32.1 \\
\hline py-2\#3 & & -29.8 \\
\hline py-2\#4 & & -23.9 \\
\hline
\end{tabular}

801C-24R2,36 - 693.0 mbsf

py-1* pyrite associated with saponite-rich vein $\quad-38.4$

py-2\#1 thin pyrite veinlet $(<0.1 \mathrm{~mm}) \quad-44.9$

801C-27R1,50 - 720.2 mbsf

py-1* -7.0

$-36.5$

$-42.3$

$-43.4$

py-2\#1

dissiminated pyrite grains lining non-

$-1.4$

py-2\#2 mineralized fracture and extending $2 \mathrm{~mm} \quad-3.8$

py-2\#3 within basalt groundmass -5.8

py-2\#4

$-28.3$

801C-27R1,50 - 720.2 mbsf

py-3\#1 dissiminated pyrite grains within basalt $\quad-10.4$

py-3\#2 groundmass

$-7.8$

801C-37R1,83 - 814.1 mbsf

$-38.9$

$-45.3$

py-1\#1

pyrite grains with framboidal-like texture

0.2

py-1\#2 within porous basalt groundmass

$-3.3$

py-1\#3

py-2\#1 polycrystalline pyrite aggregates within

$-2.3$

py-2\#2 porous basalt groundmass $\quad-3.2$

py-3\#1 Coarse pyrite grain lining basalt vesicule 1.3

py-3\#2 -0.6

$-26.3$

py-1\#8 Coarse pyrite grain lining basalt vesicule -8.6

py-1\#9 -17.2

-41.7 801C-37R5,30 - 818.8 mbsf

-45.3 py-1* dissiminated fine-grained pyrite within -1.0

$-43.6$

$-7.4$

$-7.1$

$-10.8$

$-5.9$

$-27.1$

$-7.7$

$-43.7$

$-8.8$ coarse-grained, porous basalt

py-2\#1 groundmass

\section{C-39R2,28 - 834.0 mbsf}

py-1\#1

$-31.0$

py-1\#2 pyrite-rich veinlet $(0.5 \mathrm{~mm}$ thick) within $\quad-33.2$

py-1\#3 fine grained basalt

py-1\#4

$-11.4$

${ }^{*} \delta^{34} S$ values obtained on micro-drilled sulfide grains (gaz-source mass spectrometer) 
Table 3: Multiple sulfur isotope composition of secondary sulfide in ODP Hole 801C normalized to VCDT scale

\begin{tabular}{|c|c|c|c|c|c|c|c|}
\hline Sample & $\delta^{33} \mathrm{~S}$ & $\delta^{34} \mathrm{~S}$ & $\Delta^{33} S$ & $\delta^{33} \mathrm{~S}^{*}$ & $\delta^{34} \mathrm{~S}^{*}$ & $\Delta^{33} S^{*}$ & Description \\
\hline \multicolumn{8}{|c|}{ Sample 801C-17R1,100 } \\
\hline \#2 & -20.541 & -39.665 & -0.114 & -20.755 & -40.473 & 0.089 & \multirow{5}{*}{$\begin{array}{l}\text { polycrystalline pyrite grain dissiminated along } \\
\text { fracture in basalt groundmass with minor } \\
\text { carbonate and saponite }\end{array}$} \\
\hline \#3 & -20.656 & -39.886 & -0.115 & -20.872 & -40.703 & 0.090 & \\
\hline \#4 & -20.418 & -39.422 & -0.116 & -20.629 & -40.220 & 0.084 & \\
\hline \#5 & -21.529 & -41.521 & -0.146 & -21.764 & -42.408 & 0.076 & \\
\hline$\# 6$ & -11.066 & -21.385 & -0.053 & -11.128 & -21.617 & 0.005 & \\
\hline \multicolumn{8}{|c|}{ Sample 801C-43R1.29/V } \\
\hline$\# 7$ & -19.178 & -37.055 & -0.095 & -19.364 & -37.759 & 0.082 & \multirow{2}{*}{$\begin{array}{l}\text { polycrystalline marcasite aggregate with minor } \\
\text { pyrite dissiminated in thick carbonate-rich vein }\end{array}$} \\
\hline \#8 & -17.881 & -34.556 & -0.085 & -18.043 & -35.167 & 0.068 & \\
\hline \multicolumn{8}{|c|}{ Sample $801 C-23 R 1,45$} \\
\hline$\# 9$ & -13.356 & -25.762 & -0.089 & -13.446 & -26.100 & -0.005 & $\begin{array}{l}\text { local pyrite enrichment (polycrystalline } \\
\text { aggregates) associated with carbonate-rich } \\
\text { vesicules (1-3mm wide) }\end{array}$ \\
\hline \multicolumn{8}{|c|}{ Sample 801C-9R1,32 } \\
\hline$\# 12$ & -11.496 & -22.121 & -0.104 & -11.563 & -22.369 & -0.042 & $\begin{array}{l}\text { polycrystalline marcasite aggregate dissiminated } \\
\text { in basalt groundmass }\end{array}$ \\
\hline
\end{tabular}



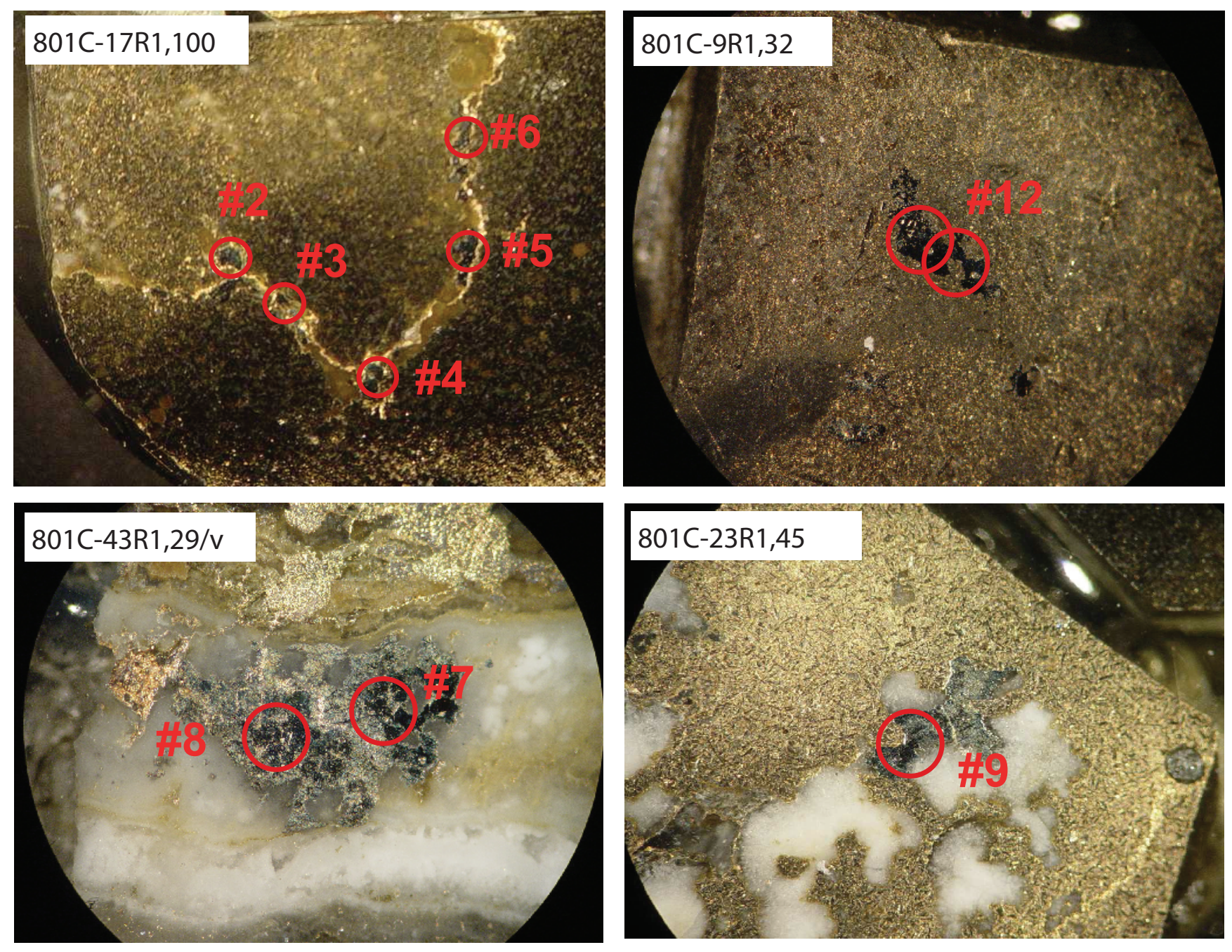

Supplementary Material : Photograph of polished section of basalt with secondary sulfides (pyrite, marcasite) analyzed for multiple $S$ isotopes. Red circles correspond to micro-drilled areas and analysis numbers are the same as in Table 3. 